University of South Florida

DIGITAL COMMONS

Digital Commons @ University of

@ UNIVERSITY OF SOUTH FLORIDA

South Florida

$11-15-1991$

\title{
The Phytoplankton Bloom in the Northwestern Arabian Sea During the Southwest Monsoon of 1979
}

John C. Brock

University of Colorado

Charles R. McClain

NASA Goddard Space Flight Center

Mark E. Luther

University of South Florida, mluther@usf.edu

William W. Hay

University of Colorado

Follow this and additional works at: https://digitalcommons.usf.edu/msc_facpub

Part of the Marine Biology Commons

\section{Scholar Commons Citation}

Brock, John C.; McClain, Charles R.; Luther, Mark E.; and Hay, William W., "The Phytoplankton Bloom in the Northwestern Arabian Sea During the Southwest Monsoon of 1979" (1991). Marine Science Faculty Publications. 83.

https://digitalcommons.usf.edu/msc_facpub/83

This Article is brought to you for free and open access by the College of Marine Science at Digital Commons @ University of South Florida. It has been accepted for inclusion in Marine Science Faculty Publications by an authorized administrator of Digital Commons @ University of South Florida. For more information, please contact digitalcommons@usf.edu. 


\title{
The Phytoplankton Bloom in the Northwestern Arabian Sea During the Southwest Monsoon of 1979
}

\author{
John C. Brock, ${ }^{1,2}$ Charles R. McClain, ${ }^{3}$ Mark E. Luther, ${ }^{4}$ and William W. Hay ${ }^{1}$

\begin{abstract}
The biological variability of the northwestern Arabian Sea during the 1979 southwest monsoon has
\end{abstract} \\ been investigated by the synthesis of satellite ocean color remote sensing with analysis of in situ \\ hydrographic and meteorological data sets and the results of wind-driven modeling of upper ocean \\ circulation. The phytoplankton bloom in the northwestern Arabian Sea peaked during August- \\ September, extended from the Oman coast to about $65^{\circ} \mathrm{E}$, and lagged the development of open-sea \\ upwelling by at least 1 month. In total, the pigment distributions, hydrographic data, and model results \\ all suggest that the bloom was driven by spatially distinct upward nutrient fluxes to the euphotic zone \\ forced by the physical processes of coastal upwelling and offshore Ekman pumping. Coastal upwelling \\ was evident from May through September, yielded the most extreme concentrations of phytoplankton \\ biomass, and along the Arabian coast was limited to the continental shelf in the promotion of high \\ concentrations of phytoplankton. Upward Ekman pumping to the northwest of the Somali Jet axis \\ stimulated the development of a broad open-sea phytoplankton bloom oceanward of the Oman shelf. \\ Vertical mixing during the 1979 southwest monsoon was apparently not a primary cause of the \\ regional-scale phytoplankton bloom.
}

\section{INTRODUCTION}

Ship-based observations of phytoplankton blooms are limited by their spatial and temporal variability. Ocean color shifts from blue to green with increasing concentration of phytoplankton pigments, and coastal zone color scanner (CZCS) sensor measurements of ocean color can provide quantitative estimates of near-surface phytoplankton pigment concentrations. The pigments of relevance to remote sensing are chlorophyll $a$ and phaeophytin $a$, and remote sensing of the sum of these pigments is an index of phytoplankton biomass.

Aside from the capacity to globally map the concentration of chlorophyll $a$ in the world's oceans, satellite ocean color images have great utility in studies of the major physical and chemical processes that act to drive marine biological activity at the most basic level. The coupling of visible-band ocean remote sensing with concurrent ancillary wind and hydrographic data in multidisciplinary studies holds great promise for increasing understanding of the marine biological pump [Brewer et al., 1986; Moore and Bolin, 1986; McClain et al., 1990]. Various schemes can relate phytoplankton biomass to primary productivity and the development of such models is an active area of research [Esaias, 1980; Yentsch, 1983; Platt and Sathyendranath, 1988].

The purpose of this paper is to examine the relations between wind-driven ocean circulation and oceanic phytoplankton blooms in the northwestern Arabian Sea, a classic region for atmospheric forcing of upper ocean circulation [Wyrtki, 1973]. The primary objectives are to describe the

\footnotetext{
${ }^{1}$ Cooperative Institute for Research in Environmental Sciences, University of Colorado, Boulder.

${ }^{2}$ Now at Biological Oceanography Division, Bedford Institute of Oceanography, Dartmouth, Nova Scotia, Canada.

${ }^{3}$ Oceans and Ice Branch, NASA Goddard Space Flight Center, Greenbelt, Maryland.

${ }^{4}$ Department of Marine Science, University of South Florida, Saint Petersburg.

Copyright 1991 by the American Geophysical Union.

Paper number 91JC01711.

0148-0227/91/91JC-01711\$05.00
}

evolution of summer phytoplankton biomass during the First GARP Global Experiment (FGGE) in 1979, and to evaluate the relative importance of different processes in producing the phytoplankton bloom.

Within this study the 1979 southwest monsoon phytoplankton bloom is conceived to result from physical processes that act to inject nutrients into the euphotic zone. The physical processes assessed are vertical mixing, coastal upwelling, the offshore advection of water upwelled along the Arabian coast, and Ekman pumping driven by the curl of the wind stress. Following the observation of Molinari et al. [1986] that the Arabian Sea directly off Arabia underwent positive net heat gain throughout the southwest monsoon of 1979, the possibility that convective overturning promoted algal production is discounted and is not examined in any detail in this study. Other processes that may affect vertical nutrient fluxes and phytoplankton biomass, for example, salt finger convection and zooplankton grazing, are not considered within this paper.

\section{Background}

A prominent zonal subsurface front at $10^{\circ} \mathrm{S}$ separates the high-oxygen, low-nutrient southern Indian Ocean from the low-oxygen, high-nutrient northern Indian Ocean [Wyrtki, 1973]. In the Arabian Sea, nutrient levels increase sharply with depth above $200 \mathrm{~m}$ near the base of the pycnocline. High levels of phosphate, nitrate, and silicate are found just below or within the limits of the euphotic zone at depths of 50 to $100 \mathrm{~m}$. As expected, the nutrient concentration trends are opposite to those observed for oxygen, which drops sharply from $5 \mathrm{~mL} / \mathrm{L}$ at the surface to $0.1 \mathrm{~mL} / \mathrm{L}$ below about $200 \mathrm{~m}$ [Ryther and Menzel, 1965; Ryther et al., 1966; Wyrtki, 1971; McGill, 1973].

\section{Monsoon Atmospheric Circulation Over the Arabian Sea}

Driven by regional changes in the global-scale atmospheric circulation, the monsoonal wind system of the Indian Ocean causes a striking semiannual reversal of the surface currents in the Arabian Sea and the Bay of Bengal. The southwest monsoon develops annually during May as the 


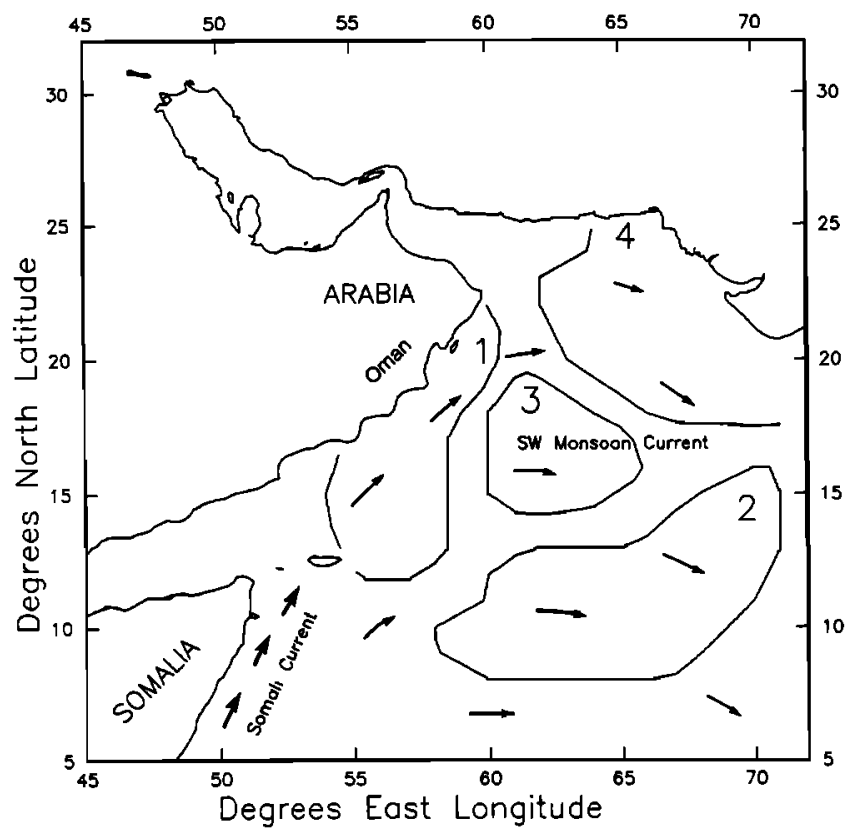

Fig. 1. Map of the Arabian Sea depicting currents active during the southwest monsoon [Wyrtki, 1973] and hydrographic areas 1 through 4 of Colburn [1975].

prevailing pressure gradient forces air to the northeast across the Arabian Sea. The surface low level southeasterly trade winds of the southern hemisphere extend across the equator to become southerlies or southwesterlies in the northern hemisphere. Hastenrath and Lamb [1979] used ship reports for the period 1911 to 1970 to provide an account of the low level meteorology of the Indian Ocean, including the surface southwest monsoon circulation. The frictional stresses of these southwesterly winds in turn drive the Somali Current and the Southwest Monsson Current in the Arabian Sea (Figure 1). Coastal upwelling develops off Oman and Somalia, and later Ekman pumping spreads upwelling throughout the northwestern Arabian Sea [Wyrtki, 1973; Smith and Bottero, 1977; Swallow, 1983; Bauer et al., 1991].

Fu et al. [1983] examined the summer monsoon wind field over the Indian and western Pacific oceans, analyzing surface wind data for 1860 through 1970 contained in marine data files available from the National Climate Data Center. They recognized three branches of intensified southwest monsoon wind flow, each to the east of a low pressure trough, and located in the western Arabian Sea, the Bay of Bengal, and the South China Sea. Embedded in the western Arabian Sea branch is a low level jet stream, the Somali or Findlater Jet. It reaches higher wind speeds of shorter seasonal duration than those observed in the surface wind field of the Asian summer monsoon elsewhere.

A series of studies by Findlater [1969a, $b, 1974]$ in the late 1960 s and early 1970s revealed the presence of this major low level air current in the western periphery of the monsoon regime and centered at an elevation of about $1.5 \mathrm{~km}$ (Figure 2). During the northern summer this 3-km-thick airflow originates in the southeast trade winds of the South Indian Ocean, passes just to the north of Madagascar, heads north across the flat arid lands of eastern Kenya, Ethiopia, and Somalia, and finally crosses the Arabian Sea. The monthly mean airflows in the Somali Jet for the months of June, July, and August are similar, showing wind speed maxima near the northern tip of Madagascar and immediately downstream from the Somali coast, a wind speed minimum along the jet axis near the equator, and bifurcation of the jet as it crosses the Arabian Sea [Findlater, 1977].

Several researchers have examined the evolution of the low level airflow over the Arabian Sea during the onset of the 1979 southwest monsoon. From an analysis of moisture and mean tropospheric enthalpy distributions based on FGGE data for May and June 1979, Pearce and Mohanty [1984] recognized two main phases of the southwest monsoon onset. An initial moisture increase over the Arabian Sea took place during the latter part of May and the first week of June, concurrent with the development of synoptic and mesoscale disturbances. A rapid intensification of the wind field followed, beginning about June 10 . This second phase was accompanied by a large increase in latent heat release, a large-scale positive feedback process. Finally, the southwest monsoon became fully developed over the Arabian Sea by mid-June, with reversed, large-scale, cross-equatorial airflow and maxima in atmospheric heating, moisture, and moisture convergence in the region from $10^{\circ}$ to $20^{\circ} \mathrm{N}$ and $60^{\circ}$ to $120^{\circ} \mathrm{E}$ [Pearce and Mohanty, 1984].

Krishnamurti et al. [1981] made use of the Summer Monsoon Experiment (MONEX) data sets also collected during May and June 1979, including winds from geostationary satellites, constant level balloons, and windsondes dropped from aircraft, and World Weather Watch data, to examine the onset of low level flow over the Arabian Sea. These researchers found that over the central Arabian Sea the kinetic energy of the wind field increased by an order of magnitude 1 week prior to the onset of monsoon rain over central India. Also, a cyclonic onset vortex formed over the northern Arabian Sea on June 14, just to the north of the strong low level jet.

\section{Response of the Arabian Sea to the Southwest Monsson}

Prominent features of the ocean response to the southwest monsoon circulation within the Arabian Sea include the northeastward Somali Current, the eastward Southwest Monsoon Current, regions of strong coastal upwelling off

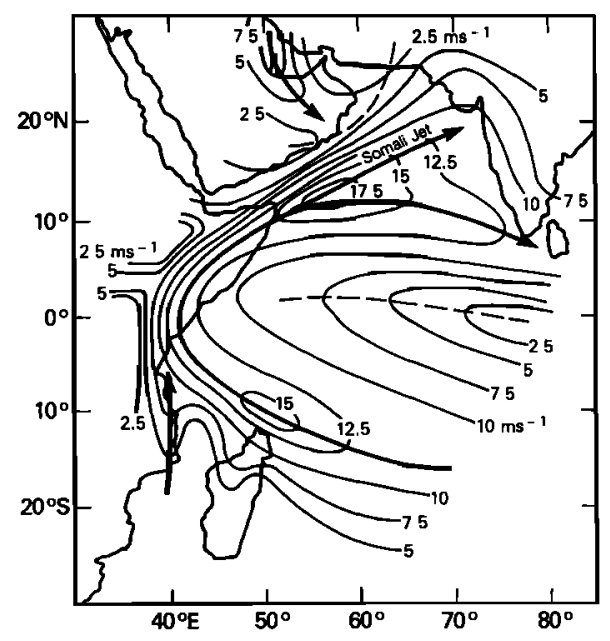

Fig. 2. July mean wind field at $1 \mathrm{~km}$ over the Arabian Sea showing the Somali Jet (modified after Findlater [1981]). 
TABLE 1. Data Sets

\begin{tabular}{|c|c|c|}
\hline Parameter & Source & Comments \\
\hline CZ CS images & NASA GSFC & $\begin{array}{l}\text { surface pigment color concentration } \\
\text { at } 4-\mathrm{km} \text { resolution }{ }^{*}\end{array}$ \\
\hline 1000-mbar FGGE winds & ECMWF & $\begin{array}{l}\text { wind speed* } \\
\text { wind stress* } \\
\text { Ekman transport* } \\
\text { Ekman upwelling* }\end{array}$ \\
\hline Sea surface temperature & $\mathrm{CAC}$ & SST at $2^{\circ}$ resolution \\
\hline Mixed-layer depth & Levitus $[1982]$ & climatology based on $0.5^{\circ}$ criterion \\
\hline Vertical temperature distribution & NOAA NODC & monthly temperature sections \\
\hline
\end{tabular}

NASA GSFC, NASA Goddard Space Flight Center; ECMWF, European Center for Medium Range Weather Forecasts; CAC, Climate Analysis Center; NOAA NODC, National Ocean Data Center, National Oceanic and Atmospheric Administration.

*Derived field.

Somali and Arabia, a weaker upwelling off northwestern India, broad-scale open-sea upwelling in the northwestern Arabian Sea, and the presence of numerous mesoscale eddies. The Somali Current is a strong western boundary current reaching a maximal transport estimated at $65 \mathrm{~Sv}$, mostly in the upper $200 \mathrm{~m}$. High speeds of up to $200 \mathrm{~cm} / \mathrm{s}$ have been measured in the Somali Current; this rapid current leads to a strong baroclinic adjustment along the Somali coast that extends to about $1000 \mathrm{~m}$. In 1964 the surface water upwelled off Somalia dropped to a minimum temperature of $13.2^{\circ} \mathrm{C}$, suggesting a depth of origin of about $200 \mathrm{~m}$ [Wyrtki, 1973; Bruce, 1974].

The southwest monsoon circulation off southern Arabia is poorly understood. In comparison to the Somali Current, the boundary current along Oman is relatively weak, but upwelling is more persistent, and the region observed to undergo upwelling is more extensive. Previous work has suggested two separate mechanisms for the southwest monsoon upwelling off Arabia: a coastal upwelling due to Ekman divergence of surface water offshore, and an open-sea upwelling due to Ekman pumping driven by the strong positive wind stress curl to the northwest of the axis of the Somali Jet [Bottero, 1969; Smith and Bottero, 1977; Swallow, 1983].

The surface concentrations of phosphate, nitrate, and silicate in the western Arabian Sea during the southwest monsoon are high [Ryther et al., 1966; Aruga, 1973; Krey, 1973; McGill, 1973; Wyrtki, 1973; Swallow, 1983]. The southwest monsoon chart of Wyrtki [1971] shows phosphate maxima above $1.0 \mu M$ at sites along the coasts of Somalia and Oman, dropping to less than $0.2 \mu M$ to the southeast. The summer distributions for nitrate and silicate provided by Wyrtki [1971] are similar. Both display highs exceeding 10.0 $\mu M$ off Somalia and Oman.

The high biological productivity of the northwestern Arabian Sea has been attributed to the presence of these unusually high concentrations of nitrate, phosphate, and silicate at shallow depths within the euphotic zone [Ryther and Menzel, 1965; Ryther et al., 1966; Kuz'menko, 1973]. Qasim [1977, 1982] combined the International Indian Ocean Expedition (IIOE) data of Ryther et al. [1966] and other IIOE participants with additional biological measurements to describe the distributions of primary, secondary, and tertiary biological production in the Indian Ocean. This compilation showed integrated mean primary productivity for the euphotic zone of the Arabian Sea, with maxima exceeding $1.0 \mathrm{~g} \mathrm{C} / \mathrm{m}^{2} / \mathrm{d}$ adjacent to the Gulf of Oman, off southwestern Oman about Salalah, and off Somalia. Currie et al. [1973] prepared transects along the Oman coast based on the Discovery data set collected in July and August, 1963. These transects show a correlation between nutrients and both chlorophyll $a$ and zooplankton biomass.

The variation of the primary biological productivity of the Indian Ocean with the annual monsoon cycle was studied by Kabanova [1968] using data collected by a number of expeditions from 1959 to 1965 . Kabanova [1968] produced maps of primary productivity in the photosynthetic layer for both winter and summer. These show strong seasonal changes within the Arabian Sea. During the northeast monsoon productivity in the northwestern Arabian Sea is less than 0.1 g C $/ \mathrm{m}^{2} / \mathrm{d}$. During the southwest monsoon, euphotic zone primary production rises above $1.1 \mathrm{~g} \mathrm{C} / \mathrm{m}^{2} / \mathrm{d}$ over all of the northwestern Arabian Sea. Krey [1973] provided a qualitative summary of the association of the larger phytoplankton found in the northwestern Arabian Sea, and listed diatoms, dinoflagellates, and blue-green algae as dominant.

\section{Methods}

The data sets used in this study are coastal zone color scanner images for 1979, the 1000-mbar FGGE wind fields, NOAA Climate Analysis Center (CAC) sea surface temperature (SST) data, Levitus [1982] mixed-layer depth fields, and NOAA National Ocean Data Center (NODC) expendable bathythermograph (XBT) profiles (Table 1).

A total of 35 CZCS images acquired during May through September of 1979 were processed to depict surface pigment concentration at 4-km spatial resolution within $10^{\circ}$ to $27^{\circ} \mathrm{N}$ and $50^{\circ}$ to $67^{\circ} \mathrm{E}$ (Figure 3 ). The SEAPAK software package developed and implemented at NASA Goddard Space Flight Center (GSFC) was used for all CZCS processing operations. SEAPAK is a comprehensive satellite image analysis system oriented specifically toward the processing of CZCS and AVHRR imagery and ancillary environmental data [Darzi et al., 1989]. The CZCS archive maintained by the National Space Science and Data Center at NASA Goddard Space Flight Center was first browsed on video disk [Feldman et al., 1989] to identify all usable CZCS scenes of the northwestern Arabian Sea acquired during May through September 1979. The entire data set of level 1 scenes was ingested at a factor of 4 subsampling in order to prepare a regional time series of overview images covering the north- 


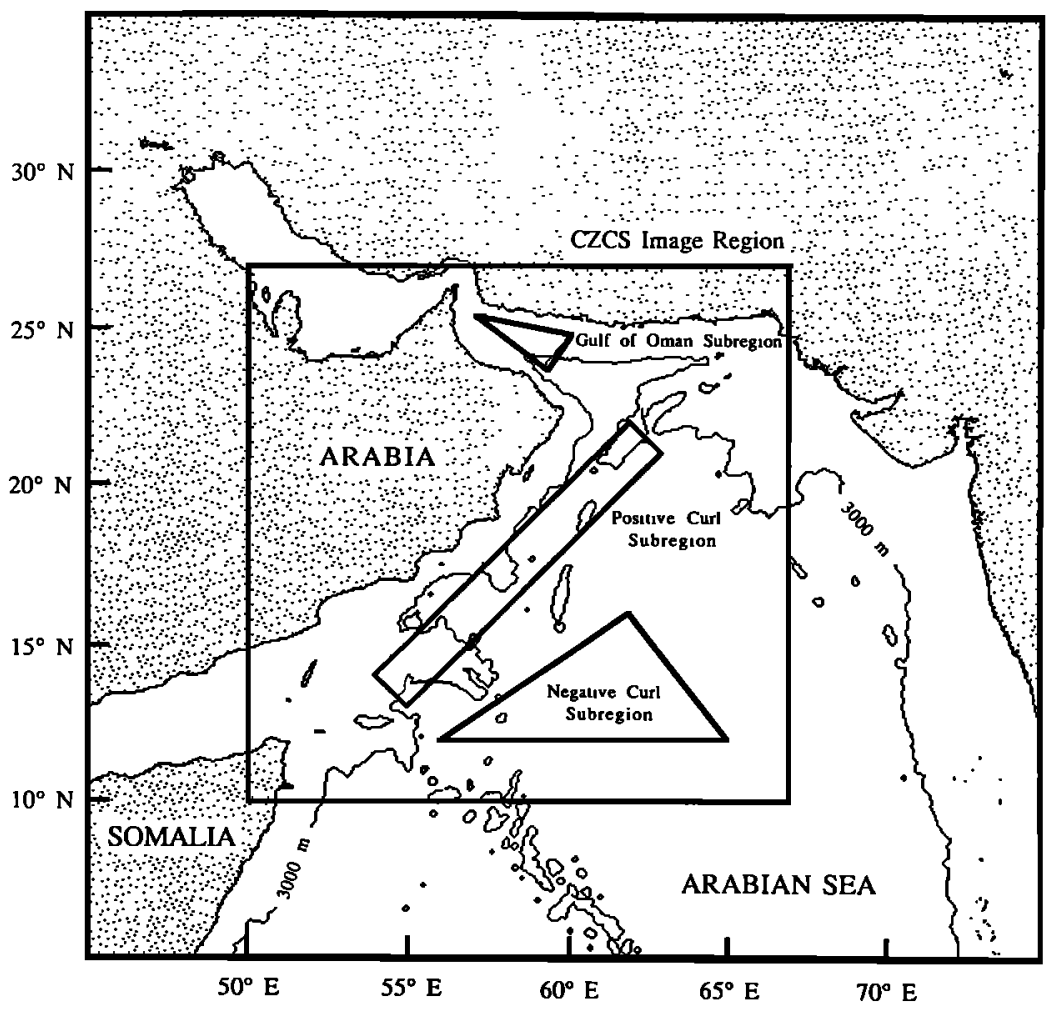

Fig. 3. Location map depicting the CZCS image region and mean pigment concentration subregions. Contours depict the bathymetry at $3000 \mathrm{~m}$ depth.

western Arabian Sea at one-sixteenth the original spatial resolution (Figure 4).

Ångström exponents used in processing the CZCS data set were obtained using the "clear water" radiance concept described by Gordon and Clark [1981]. Clear water CZCS image sites with phytoplankton pigment concentrations less than $0.25 \mathrm{mg} / \mathrm{m}^{3}$ were selected on a time series of several separate scenes collected over the western Arabian Sea during May-September 1979. Normalized water radiances were derived at each site for a variety of Ångström exponents $n(\lambda)$, and exponents at 520 and $550 \mathrm{~nm}$ that consistently yielded clear water radiance values similar to those

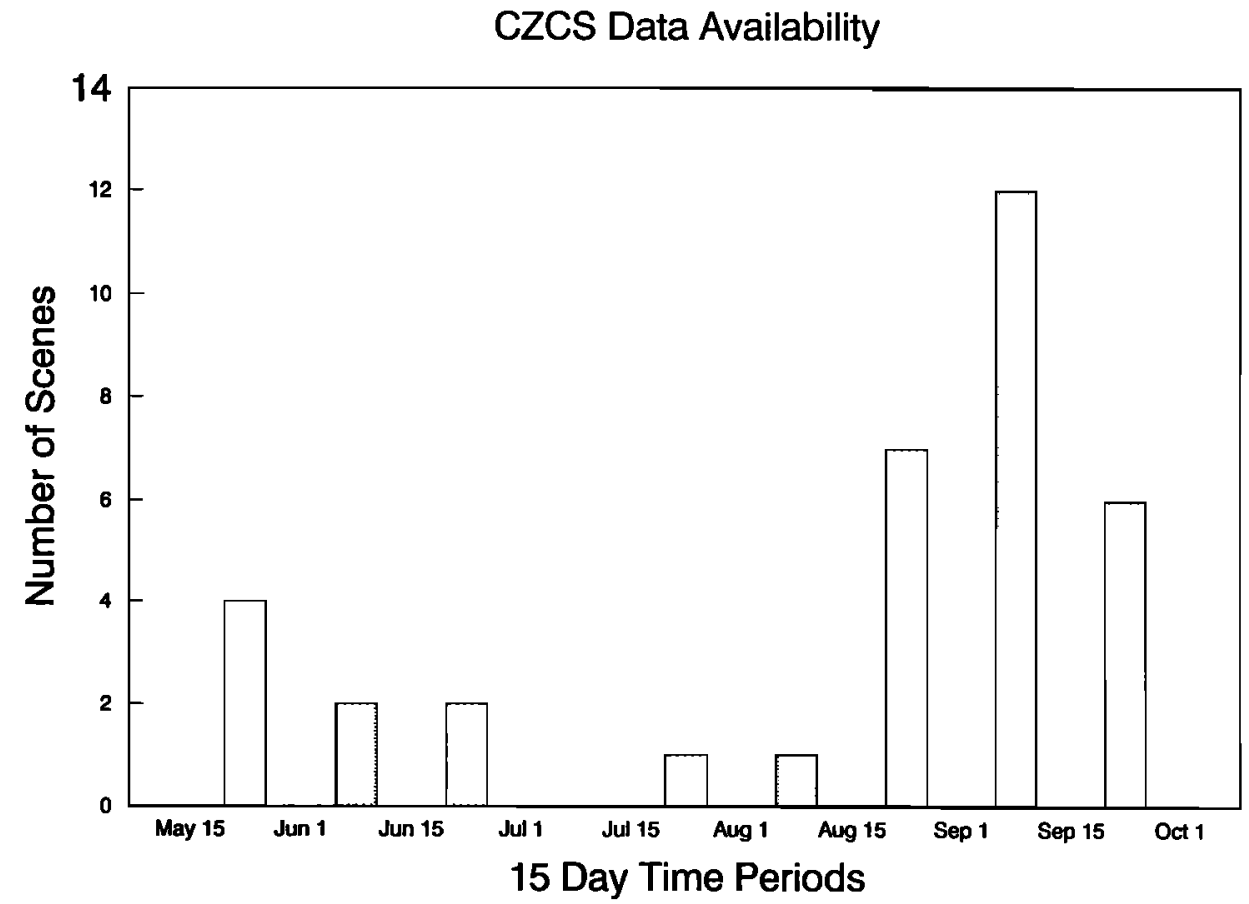

Fig. 4. CZCS data availability for the study region for May-September 1979. 

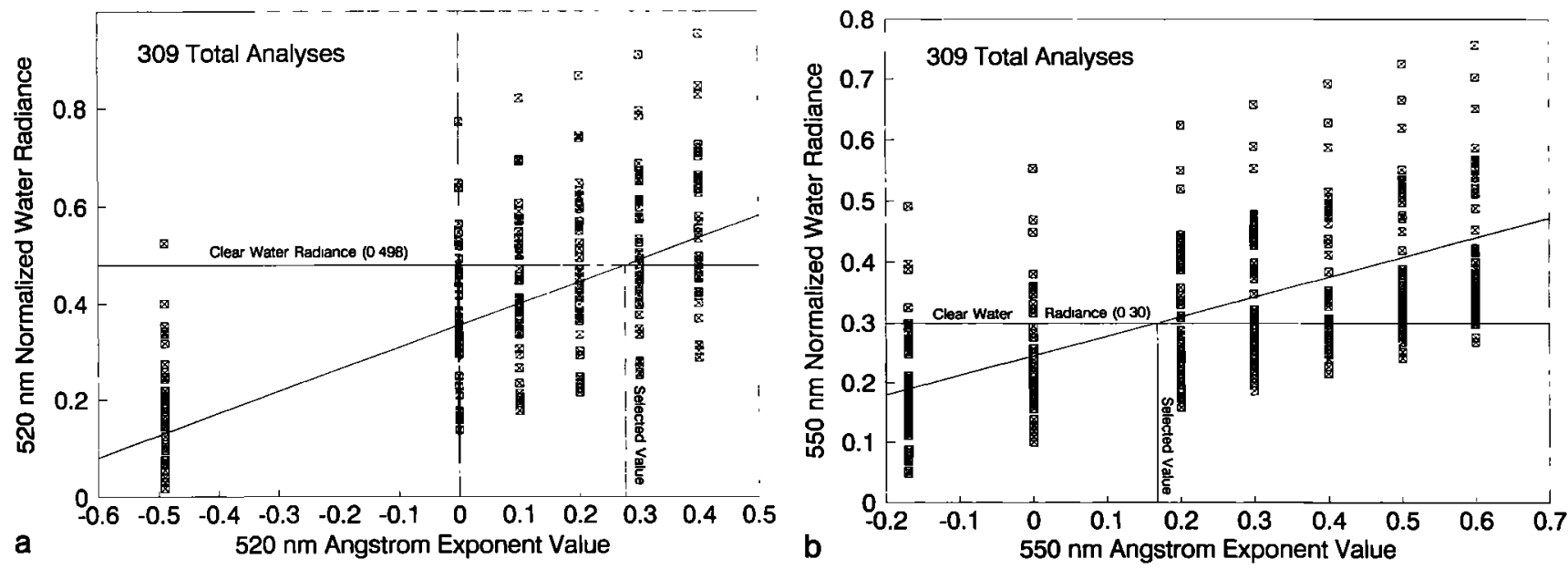

Fig. 5. Plot of (a) CZCS band 2 Ångström exponent value versus band 2 normalized water radiance and (b) CZCS band 3 Àngström exponent value versus band 3 normalized water radiance $\left(\mathrm{mW} / \mathrm{cm}^{2} \mu \mathrm{m} s r\right)$ showing selection of Ångström value yielding clear water radiance value. Each symbol on the plot indicates a normalized water radiance determination at a clear water site on one of several CZCS images acquired during the early phase of the 1979 southwest monsoon.

reported by Gordon and Clark [1981] were applied in subsequent processing. Within this analysis, the relationship proposed by Gordon et al. [1983] to derive the Ångström exponent for $443 \mathrm{~nm}(n(443))$ was applied:

$$
n(443)=\frac{[n(520)+n(550)]}{2}
$$

Exponent values near 0.2 were obtained by this procedure for $443 \mathrm{~nm}, 520 \mathrm{~nm}$, and $550 \mathrm{~nm}$ (Figures $5 a$ and $5 b$ ). These exponents are within the -0.5 to +0.5 range cited by Gordon [1990] as typical for CZCS imagery. This approach was adopted in order to define a more realistic regional set of Angström exponents than were used in the CZCS global processing $(n(443)=0.12, n(520)=0.0, n(550)=0.0)$ [Feldman et al., 1989]. A scene-by-scene determination such as that used by McClain et al. [1988] was not employed because "clear water" sites within the scenes were not always available during the late phase of the 1979 southwest monsoon.

High aerosol radiance due to an abundance of atmospheric dust, as well as strong sensor electronic overshoot [Mueller, 1988] or "ringing" downscan of boundaries between highly reflective desert land or clouds and ocean, presented imaging problems in the study region, and necessitated the development of specialized correction procedures. A level 1, band 4 threshold set at grey level 254 was used to avoid processing pixels with saturated $670-\mathrm{nm}$ radiances. Also, following a study of the occurrence of sensor ringing in the level $1 \mathrm{CZCS}$ data set, a procedure was developed to recognize rapid grey level changes along individual scan lines in band 4 and to flag a number of subsequent downscan pixels in the level 2 image as invalid. The threshold used for the bright side of the edge was 210 counts, the brightness change threshold was 10 grey levels, and the number of downscan pixels flagged was set to 4 [Brock et al., 1990].

The branching, two-channel bio-optical algorithm of Gordon et al. [1983] was used to retrieve phytoplankton pigment concentration. This algorithm employs two empirical biooptical relationships based on data collected by a field program conducted in waters adjacent to the United States in the Atlantic, Pacific, and Gulf of Mexico. Although these algorithms were based on a limited number of stations in U.S. coastal waters, many studies have demonstrated their validity for much of the world ocean [Feldman et al., 1984; McClain et al., 1984, 1986; Abbott and Zion, 1985; Barale et al., 1986; Müller-Karger et al., 1989, 1990]. Gordon et al. [1983] report an error of the order of $30-40 \%$ in pigment concentration in the range 0.08 to $1.5 \mathrm{mg} / \mathrm{m}^{3}$ for this algorithm under a variety of atmospheric turbidities.

Once masked for the effects of wind-blown dust, sun glint, and sensor ringing, the level 2 surface pigment concentration images were transformed to a uniform cylindrical equidistant projection. The registration of all scenes to a coastline contour derived from a global coastline data set followed. Thus a spatially coregistered CZCS pigment data set for the FGGE year southwest monsoon was produced. Separate CZCS level 3 surface pigment concentration images were averaged to produce mean pigment fields [McClain et al., 1988] for the early and late phases of the monsoon. The available CZCS data allowed the generation of an early phase composite from eight scenes acquired from May 19 to June 16 and a late phase composite based on 27 scenes from August 1 to September 29 (Plates 1 and 2).

Monthly mean wind stress, Ekman horizontal transport, and Ekman upwelling velocity were calculated from the 1000-mbar FGGE III-b wind fields for May through September, 1979. This wind data set has undergone extensive refinement and validation at their source, the European Center for Medium Range Weather Forecasts (ECMWF). It has a spatial resolution of $1.875^{\circ}$ and a temporal resolution of 12 hours.

The procedure described by McClain et al. [1990] was applied to estimate surface wind stress based on the 1000mbar winds. First the wind velocity at $10 \mathrm{~m}, W_{10}$, was estimated by a $15^{\circ}$ cyclonic rotation and $30 \%$ reduction in magnitude [Thompson et al., 1983]. The standard quadratic expression with a wind-speed-dependent drag coefficient, $C_{d}$, was employed to estimate wind stress. The stress 


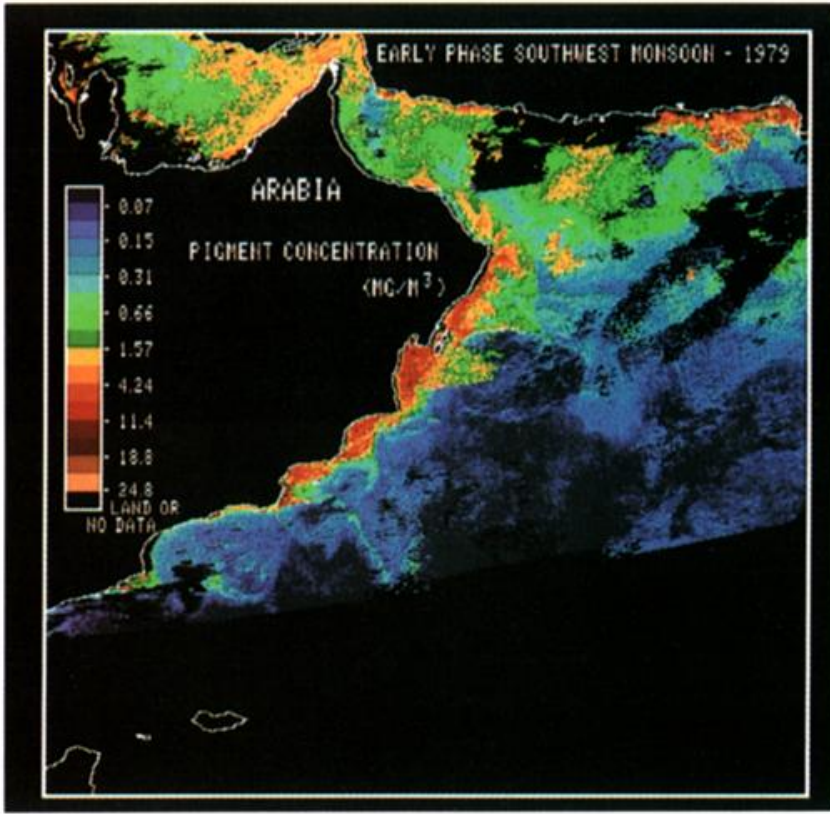

Plate 1. CZCS pigment concentration composite for the early phase of the 1979 southwest monsoon.

formulation used is similar to that of Large and Pond [1981], and may be expressed as

$$
\left(\tau_{x}, \tau_{y}\right)=\rho_{a} C_{d}\left|W_{10}\right|\left(u_{10}, v_{10}\right)
$$

where $\left(u_{10}, v_{10}\right)$ are components of $W_{10}$ and

$$
\begin{gathered}
C_{d}=0.0012 \quad 0<W_{10}<11 \mathrm{~m} / \mathrm{s} \\
C_{d}=0.00049+0.000065 W_{10} \quad 11 \mathrm{~m} / \mathrm{s}>W_{10}
\end{gathered}
$$

Once the surface wind stress has been obtained, the zonal and meridional Ekman transports $\left(U_{e}, V_{e}\right)$ are calculated by

$$
\left(U_{e}, V_{e}\right)=\frac{\left(\tau_{y}, \tau_{x}\right)}{\rho_{w} f}
$$

and the Ekman upwelling velocity $W_{e}$ is given by

$$
W_{e}=\frac{\operatorname{curl}_{z}(\tau / f)}{\rho_{w}}
$$

In these expressions, $\rho_{w}$ is the water density, $1000 \mathrm{~kg} / \mathrm{m}^{3}$, and $f$ is the Coriolis parameter. All computations on the FGGE winds were carried out on data at the 12-hour time step, followed by averaging of the derived fields to obtain monthly means. The $1.875^{\circ}$ resolution monthly wind stress, Ekman transport, and Ekman upwelling fields were interpolated using a bicubic spline technique to create images. Transformation of these wind parameter fields to an cylindrical equidistant projection resulted in a set of FGGE wind-derived environmental fields coregistered to the 4-kmresolution CZCS regional image time series for May through September of 1979. Images of monthly mean CAC SST fields for May through September of 1979 and the Levitus monthly mixed-layer depth fields were generated in a similar manner.

The NODC expendable bathythermograph data were binned by month for May-September 1979 using SEAPAK. Following the selection of stations for individual sections, these monthly XBT data files were imported into a surface modeling software package. Gridding and contouring produced

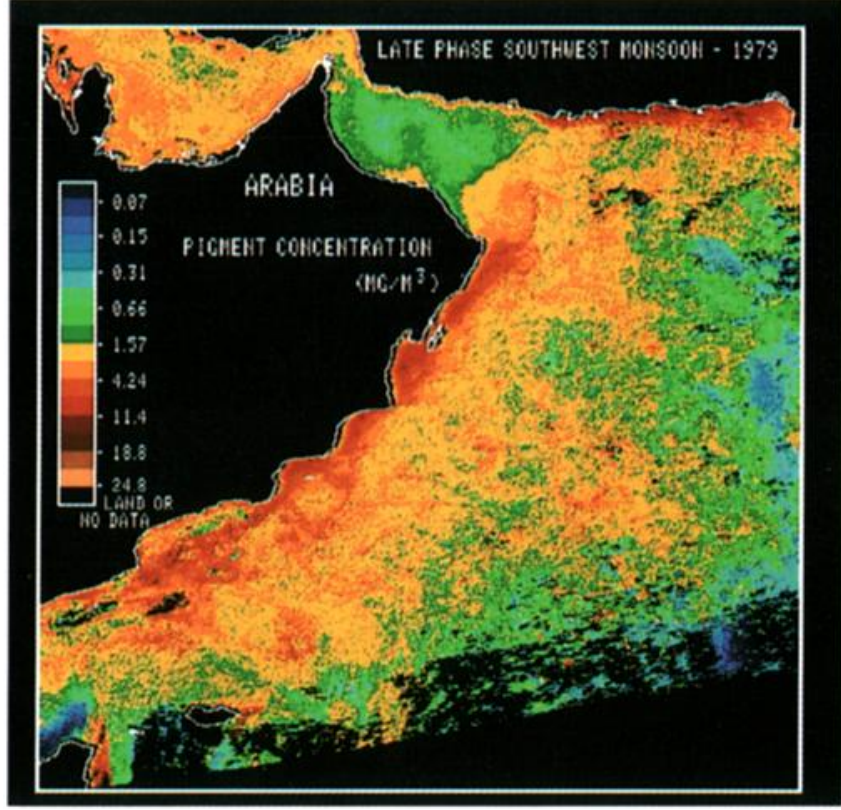

Plate 2. CZCS pigment concentration composite for the late phase of the 1979 southwest monsoon.

monthly temperature sections coincident with the MaySeptember 1979 CZCS data set.

\section{MODEL UPWELLING INDEX}

Information on ocean upwelling was derived from a winddriven numerical model of the Arabian Sea for comparison with the CZCS images. The model used is that described by Luther and O'Brien [1985], Luther et al. [1985], Luther [1987], and Simmons et al. [1988]. The model simulates the response of the upper layer of the ocean to an applied wind stress. It is a nonlinear reduced-gravity model forced by the observed winds. In the reduced-gravity approximation the density stratification of the ocean is represented by two hydrostatic, Boussinesq fluid layers of slightly different densities, with the further requirement that the depthintegrated transport in the lower layer vanishes. The model dependent variables are the upper layer thickness $H$, the zonal component of the depth-integrated upper layer transport $(U)$, and the meridional component of the depthintegrated upper layer transport $(V)$. The advantage to such a model is its inherent simplicity. As was demonstrated by Lin and Hurlburt [1981], this is the simplest model that contains the necessary physics to reproduce the observed eddy patterns in the Somali Current. Luther and O'Brien [1985] and Luther et al. [1985] show that the model faithfully reproduces most of the observed features of the seasonal cycle of the northwestern Indian Ocean circulation, such as the formation and coalescence of the two-gyre system during the southwest monsoon, the formation and decay of the energetic eddy field off the Arabian Peninsula during the fall transition, and the formation of the southwestward Somali Current with the onset of the northeast monsoon. Simmons et al. [1988] show that the model can reproduce the features observed in a particular year by comparing model fields driven by the observed winds for 1985 with extensive observations taken off the coasts of northern Somalia and the Arabian Peninsula during the fall of that year. Since the 
model physics are well known and the model fields are more easily analyzed, and because it reproduces many of the important features of the observed flows in this region, this model is ideal for use in long-term integrations to assess the importance of interannual and seasonal variability in the region. In the present study we treat the model fields as adequately simulating the ocean's response to the imposed winds and treat the variability in the model fields as an expression of that in the ocean.

The model integration discussed here is of a limited area version of the model that covers the northwestern portion of the Indian Ocean from $10^{\circ} \mathrm{S}$ to $26^{\circ} \mathrm{N}$ and from $40^{\circ} \mathrm{E}$ to $74^{\circ} \mathrm{E}$ at a resolution of $0.125^{\circ}$ zonally and $0.25^{\circ}$ meridionally. This high horizontal resolution is necessary to model the highly nonlinear flows found in the intense eddies in this region. The model geometry follows the $200-\mathrm{m}$ isobath, so that the large shallow banks around Socotra, the Seychelles, the Maldives, the Laccadives, and the Chagos Archipelago appear as land areas. These banks are typically less than $\mathbf{3 0}$ $\mathrm{m}$ deep and are dotted with reefs and small islands, so that they effectively present solid boundaries to flow. The boundary conditions at all solid (land) boundaries are the no-slip conditions: $U=V=0$. The model employs open boundary conditions along the south and along a portion of the east boundaries. The boundary condition applied there is the Sommerfeld radiation condition described by Camerlengo and O'Brien [1980]. The free parameters in the model are the reduced gravity $g^{\prime}$, the initial upper layer thickness $H_{0}$, and the Laplacian eddy viscosity coefficient $A_{\mathrm{ev}}$. For the results presented here, the model uses $g^{\prime}=0.03 \mathrm{~m} / \mathrm{s}^{2}, H_{0}=200 \mathrm{~m}$ and $A_{\mathrm{ev}}=750 \mathrm{~m}^{2} / \mathrm{s}$. The initial value of $H$ together with the value of $g^{\prime}$ determine the mean stratification. For simplicity, the model year has 360 days, with 30 days in each month.

The model is driven by objectively analyzed ship winds for 1979. The ship winds are converted to a pseudostress, which is defined as the wind velocity vector multiplied by its magnitude, $(u, v)|W|$, where $(u, v)$ is the vector wind velocity and $|W|$ is its magnitude. They are objectively analyzed onto a $1^{\circ}$ by $1^{\circ}$ latitude-longitude grid as described by Legler et al. [1989]. These wind data are interpolated in space to the model grid using the natural bicubic spline interpolant and in time using a simple linear interpolant. We assume that each monthly mean represents the value at the middle of the respective month and interpolate linearly between them to obtain pseudostress data at the model time step of $30 \mathrm{~min}$. We convert the pseudostress fields to wind stress using (2) with a constant drag coefficient equal to $1.25 \times 10^{-3}$. The drag coefficient thus becomes a parameter of the model rather than the wind analysis. The model is initialized to a state of rest, with $U=V=0$ and $H=200 \mathrm{~m}$ [Gent et al., 1983; Simmons et al., 1988]. The model is integrated forward in time for 3 years, with the annual wind cycle repeating each year. By the third year, the model produces a steady, repeating seasonal cycle. Results from the third year of this integration are used to compute an index of upwelling.

We treat the model upper layer thickness $(H)$ fields as a surrogate variable for thermocline (or pycnocline) depth. A thinning of the upper layer implies upwelling and cooler SST, while a thickening upper layer implies downwelling and warmer SST. Variations in $\boldsymbol{H}$ are indicative of variations in heat content of the upper layer of the ocean and are expected to be positively correlated with SST variations. Additionally, a thinner upper layer enhances the effect of wind-driven entrainment in lowering SST and increasing primary productivity by bringing cooler, nutrient-rich water nearer the surface where it can be more easily mixed upward, while a thicker upper layer reduces the efficiency of entrainment and allows local heating to more effectively increase SST. The model does not explicitly include thermodynamics, and in some instances thermodynamic effects will dominate the SST response; however, in the dynamically active regions of the Arabian Sea, variability in model upper layer thickness is highly correlated with SST variability, especially on longer time and space scales [Simmons et al., 1988].

As an indicator of upwelling strength, we computed the integrated, rectified upward interface displacement following Luther et al. [1990] over 5-day intervals throughout the year. We further summed the upward interface displacement from these 5-day intervals over the 2-month period preceding the monsoon onset (mid-April to mid-June) and over the 2 months after the onset which constitute the primary upwelling season of mid-June to mid-August. This time frame includes the onset and mature stages of the southwest monsoon and is the period of most active upwelling along the Arabian Peninsula. Waters above the thermocline are typically nutrient-depleted, while the waters below the thermocline are relatively nutrient-rich. We integrated only upward motions of the model interface, ignoring downward motions, since upward motions of the interface bring nutrient-rich waters closer to the surface, where they can be mixed into the euphotic zone and sustain primary productivity, while downward motions of the interface do not remove these nutrients. This is admittedly a crude index of upwelling strength. The index has the negative properties that it rectifies small-amplitude oscillations so that they may appear as large upwelling signals and that it does not account for the initial depth of the interface. For example, an upward displacement from an initial depth of $80 \mathrm{~m}$ would be more effective in bringing nutrients toward the euphotic zone than would the same displacement from an initial depth of $200 \mathrm{~m}$. It does capture the upwelling driven by the mechanisms of upward Ekman pumping and coastal Ekman divergence, shown by Smith and Bottero [1977] to be the dominant mechanisms off the Arabian Peninsula, and does compare favorably with information on upwelling strength derived from sediment data from this region [Prell et al., 1990]. It is sufficient therefore for the purpose of investigating variability in upwelling patterns in this region.

The calculated index of the upward displacement of the interface differs from the steady state Ekman upwelling $W_{e}$ of (4) in that it includes time-dependent wave and eddy driven components of upwelling that are not represented in $W_{e}$. Given the strongly time-dependent nature of the wind stress forcing in this region and the large-amplitude eddy field found here [e.g., Simmons et al., 1988] these components of the upwelling may be important.

\section{Results}

\section{Coastal Zone Color Scanner Observations}

The CZCS composite image generated from eight separate scenes acquired from May 19 to June 16, 1979, depicts high surface pigment concentrations over and near the Arabian continental shelf, with values typically exceeding $5 \mathrm{mg} / \mathrm{m}^{3}$ (Plate 1). Oligotrophic conditions occurred offshore, where pigment concentrations were generally below $0.3 \mathrm{mg} / \mathrm{m}^{3}$. 
TABLE 2. Pigment Concentration Mean Values by Subregion

\begin{tabular}{lcc}
\hline & \multicolumn{2}{c}{ Pigment, $\mathrm{mg} / \mathrm{m}^{3}$} \\
\cline { 2 - 3 } & Early Phase & Late Phase \\
\hline Gulf of Oman & 0.8 & 0.7 \\
Positive curl subregion & 0.1 & 2.8 \\
Negative curl subregion & NA & 0.6 \\
\hline
\end{tabular}

NA, not available.

Within and adjacent to the Gulf of Oman, intermediate pigment concentrations ranging up to roughly $3.0 \mathrm{mg} / \mathrm{m}^{3}$ are seen.

Following a period of minimal CZCS coverage in the month of July, 27 scenes were acquired for August and September, and a composite of these scenes depicts an extensive phytoplankton bloom extending over the northwestern Arabian Sea to about $65^{\circ} \mathrm{E}$ (Plate 2). The highest pigment concentrations exceeded $8.0 \mathrm{mg} / \mathrm{m}^{3}$ and were observed within the Oman and Pakistan continental shelf regions. Offshore within the bloom, pigment concentrations between 2.0 and $5.0 \mathrm{mg} / \mathrm{m}^{3}$ were typical. To the west of a sharp horizontal pigment gradient within the Gulf of Oman, pigment values were generally less than $1.0 \mathrm{mg} / \mathrm{m}^{3}$.

Phytoplankton pigment means were obtained for selected subregions within the early and late phase composites (Figure 3). In addition to a subregion covering the central Gulf of Oman, two subregions were defined based on the July monthly mean surface wind stress curl chart of Hastenrath and Lamb [1979]. This chart depicts strong cyclonic wind stress north of a southwest to northeast trending boundary about $500 \mathrm{~km}$ off Arabia, with anticyclonic stress to the south. The pigment means obtained for the two subregions defined by July mean positive and negative wind stress curl and those for the Gulf of Oman subregion outline the phytoplankton biomass changes that occur in response to the southwest monsoon (Table 2).

The positive curl subregion lies at the center of the bloom, and this is made apparent by the increase in mean pigment from a prebloom value of $0.1 \mathrm{mg} / \mathrm{m}^{3}$ to $2.8 \mathrm{mg} / \mathrm{m}^{3}$ for August-September. Similarly, on the basis of data from a research cruise during the southwest monsoon of 1987 , Bauer et al. [1991] found surface chlorophyll $a$ to be highest north of $17^{\circ} \mathrm{N}$ in August.

Although no CZCS coverage exists for the negative curl subregion during the early monsoon phase, a broad oligotrophic region was immediately adjacent at this time over most of the northwestern Arabian Sea. During the late phase, the negative curl subregion was to the east of the bloom and had a mean pigment value of $0.6 \mathrm{mg} / \mathrm{m}^{3}$. This subregion overlaps with hydrographic areas 2 and 3 of Colburn [1975], for which Banse [1987] has compiled ship-observed chlorophyll concentrations. Colburn's [1975] areas 2 and 3 both display seasonal peaks for mean upper $25 \mathrm{~m}$ chlorophyll concentration in August that reach 0.74 (area 3) and 0.78 (area 2) $\mathrm{mg} / \mathrm{m}^{3}$. This is in close agreement with the CZCS-derived AugustSeptember 1979 mean surface pigment concentration of 0.6 $\mathrm{mg} / \mathrm{m}^{3}$ in the negative curl subregion.

\section{FGGE Winds and Derived Fields}

During the early phase of the southwest monsoon in May and June of 1979, the FGGE wind field over the northwestern Arabian Sea became southwesterly. The southwest monsoon onset was obvious as a strong increase in wind stress from May to June (Plate 3). The appearance of the low level Somali Jet is shown in the June monthly mean wind stress field as an elongate region of maximal stress that trends northeast-southwest across the Arabian Sea immediately to the southeast of Socotra Island (Plate 3). An Ekman horizontal transport high in June that exceeded $6.0 \mathrm{~m}^{2} / \mathrm{s}$ coincided with the June wind stress maximum, but along the Arabian coast this calculated parameter was low, at values less than $1.0 \mathrm{~m}^{2} / \mathrm{s}$ (Plate 4). The extremely weak May mean winds yielded a prediction of weak Ekman downwelling over all of the northwestern Arabian Sea (Plate 5). This was rapidly altered by the vigorous arrival of the summer monsoon southwesterlies in June, which resulted in calculated upward Ekman pumping within a $400-\mathrm{km}$-wide zone that stretched from Somalia to the northeast along the Arabian Peninsula (Plate 5). The maximum monthly mean June Ekman upward velocities calculated for the core of this region near Socotra Island exceeded $0.5 \times 10^{-5} \mathrm{~m} / \mathrm{s}$.

The FGGE monthly mean southwesterly surface wind field attained peak intensity in July. Surface wind speed reached 15 $\mathrm{m} / \mathrm{s}$ within the elongated northeast-southwest region of maximal wind stress $600 \mathrm{~km}$ off Arabia (Plate 3). This was the surface manifestation of the low level Somali Jet (Plate 3). As is to be expected, the July mean total surface Ekman transport (Plate 4) based on the FGGE winds displayed a pattern spatially coincident with the wind stress distribution. At the Arabian coast the monthly mean July surface Ekman transport was estimated to be about $1.0 \mathrm{~m}^{2} / \mathrm{s}$, much less than the peak of greater than $8.0 \mathrm{~m}^{2} / \mathrm{s}$ seen $500 \mathrm{~km}$ off East Africa. Off Arabia, the calculated open-sea upwelling resulting from Ekman pumping reached its maximal intensity of 1979 in July, with upward velocities greater than $0.4 \times 10^{-5} \mathrm{~m} / \mathrm{s}$ at the core (Plate 5).

The FGGE monthly mean winds lessened during the late phase of the 1979 southwest monsoon in August and September. The maximal monthly mean August wind speed, $12 \mathrm{~m} / \mathrm{s}$, was again found along the Somali Jet axis, and the associated wind stress peak exceeded $0.16 \mathrm{~N} / \mathrm{m}^{2}$ and was centered about $300 \mathrm{~km}$ to the south of the island of Socotra (Plate 3). The Somali Jet also coincided with the horizontal Ekman transport maximum of about $6.0 \mathrm{~m}^{2} / \mathrm{s}$ (Plate 4). In August the FGGE wind analysis indicated a broad region of Ekman upwelling along the Arabian coast (Plate 5), but by September the decay of the southwest monsoon resulted in weak downward Ekman pumping over most of the Arabian Sea.

\section{Levitus Mixed-Layer Depth Fields}

The mixed-layer depth distributions shown in the May and June climatologies [Levitus, 1982] are uniform at 30 to $40 \mathrm{~m}$ except proximal to Arabia and in the Gulf of Oman, where mixed-layer depth is less than $10 \mathrm{~m}$ (Plate 6). For July, the monthly climatology reveals a deepening of the mixed layer in the central Arabian Sea, consistent with calculations of Ekman downwelling. Mixed-layer deepening at this site is greatest in August, exceeding $90 \mathrm{~m}$ within a 500-km-diameter region centered at $12^{\circ} \mathrm{N}, 64^{\circ} \mathrm{E}$. In September, shallowing of mixed-layer depth is apparent off Yemen and southern Oman, but in the central Arabian Sea the deepened mixedlayer conditions persist.

\section{Climate Analysis Center SST Fields}

The May Climate Analysis Center SST field revels a warm, equable surface temperature pattern with zonal iso- 

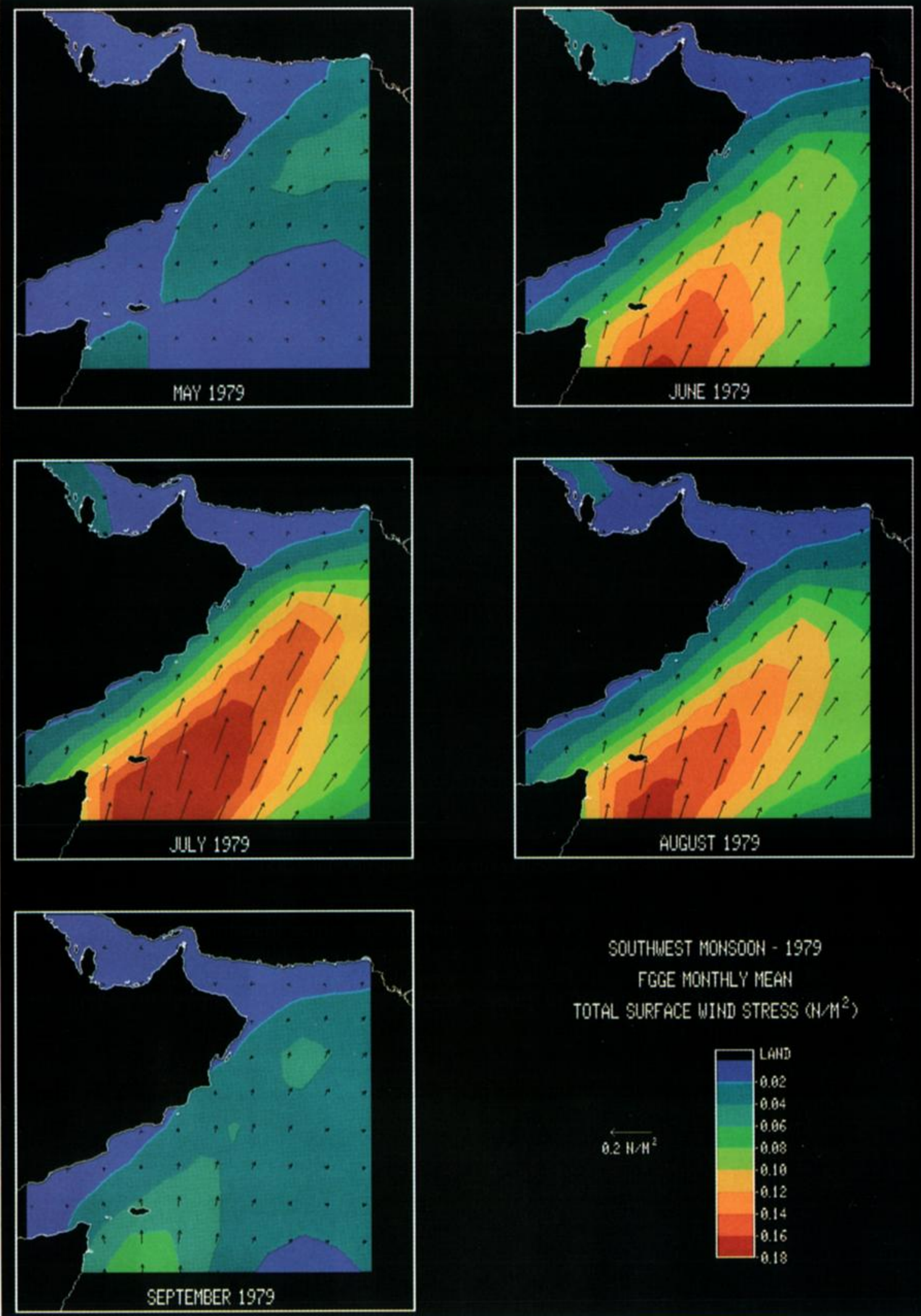

SOUTHWEST MOHSOOH - 1979

FGGE MONTHLY MEAN

TOTAL SURFACE WIND STRESS $\left(N / M^{2}\right)$

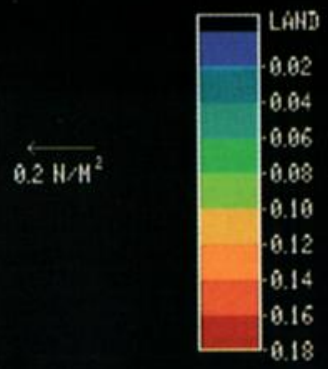

Plate 3. FGGE monthly mean wind stress fields for May-September 1979.

therms (Plate 7) increasing southward across the Arabian Sea from $28^{\circ} \mathrm{C}$ to $31^{\circ} \mathrm{C}$. The June monthly mean temperature field shows a broad region of depressed SST roughly coincident with the region of upward Ekman pumping predicted by the FGGE wind analysis. This surface cooling intensified through July and peaked in August as an extensive region below $25^{\circ} \mathrm{C}$ that extended northeast from the Somali coast nearly to the mouth of the Gulf of Oman. Although cooler 

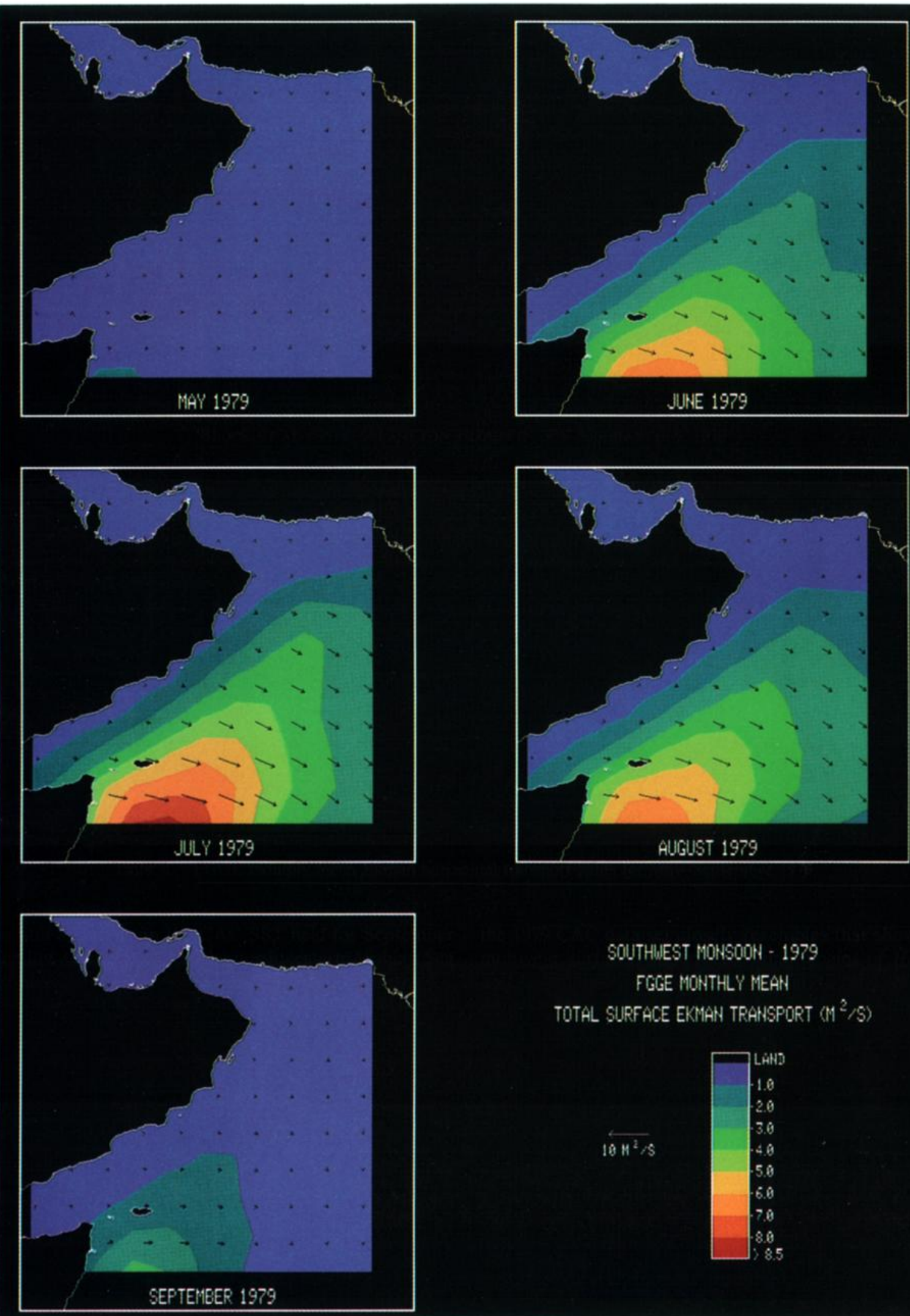

\section{SOUTHWEST MONSOOH - 1979 \\ FGGE MONTHLY MEAK:}

TOTAL SURFACE EKMAN TRAHSPORT $\left(M^{2} / 5\right)$

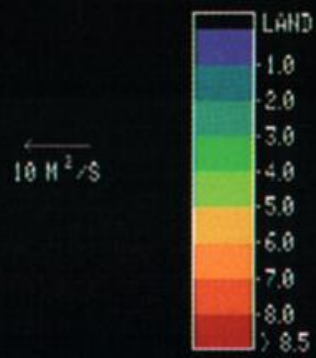

Plate 4. FGGE monthly mean Ekman horizontal transport fields for May-September 1979.

water is still apparent on the CAC SST field for September 1979, the low temperatures in the northwestern Arabian Sea began to dissipate as the southwesterly winds slacked.

The evolution of SST from May to September shown by the 1979 CAC data set closely resembles that shown by the multiyear surface temperature climatologies of Hastenrath and Lamb [1979] and Wooster et al. [1967] and the distributions for the summer of 1963 [Wyrtki, 1971]. As depicted by 

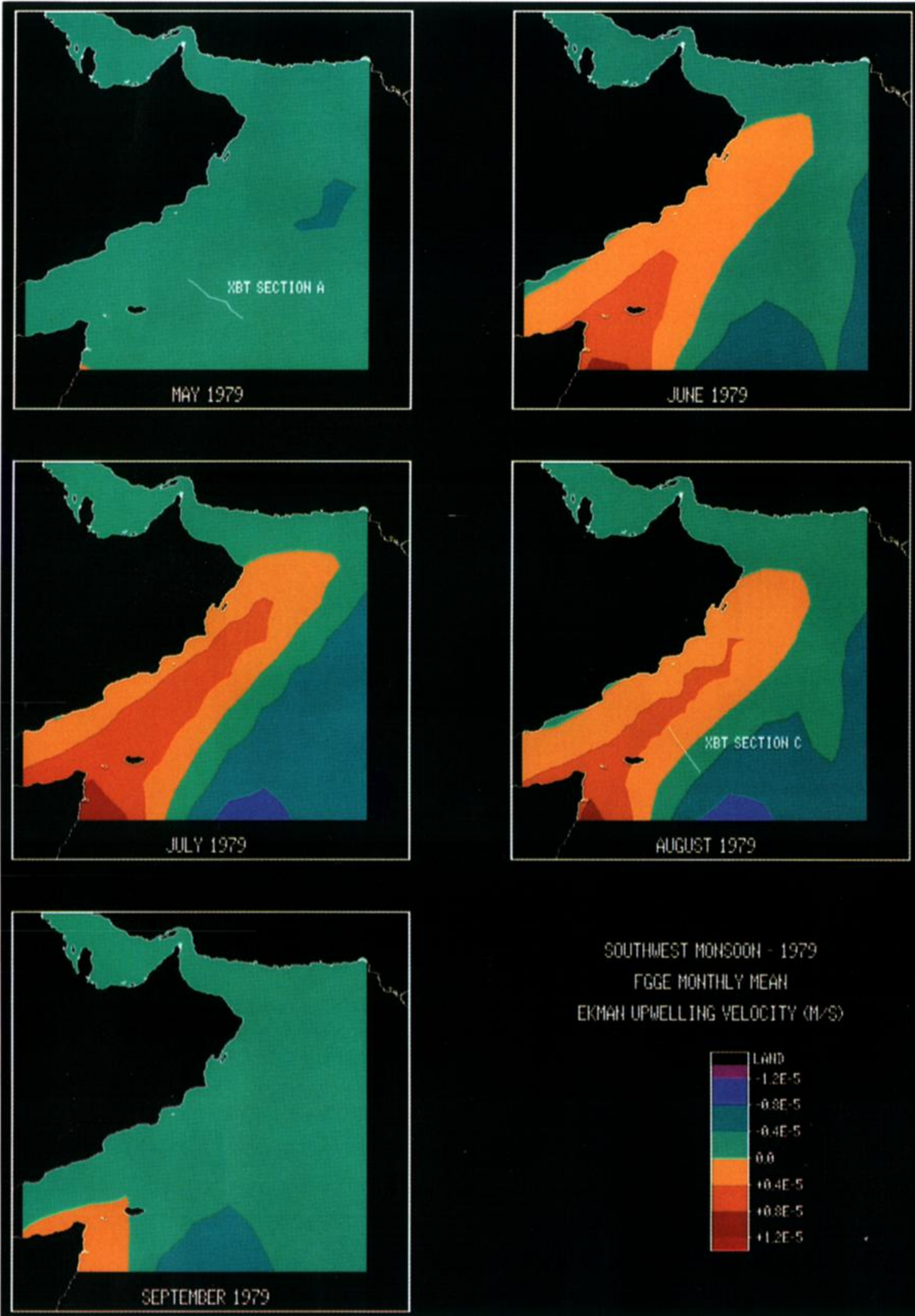

SOUTHWEST MOHKŌ̄H - 1979

FGQE MOHTHLY MEAH

EKMAN UPUELLIHGS WELOCITY (M/S)

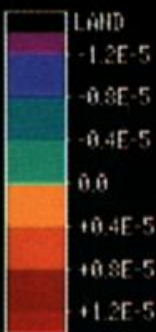

Plate 5. FGGE monthly mean Ekman vertical velocity fields for May-September 1979.

these atlases, SST across the Arabian Sea at the close of the intermonsoon in May averages about $29^{\circ} \mathrm{C}$ and shows little variability within the zonal patternof isotherms. The southwest monsoon produces dramatic changes in this pattern of
SST, as is apparent on the average August surface temperature chart of Hastenrath and Lamb [1979] and on the CAC monthly mean SST fields for 1979. By August, cooler water is at the surface over all of the western Arabian Sea; the 

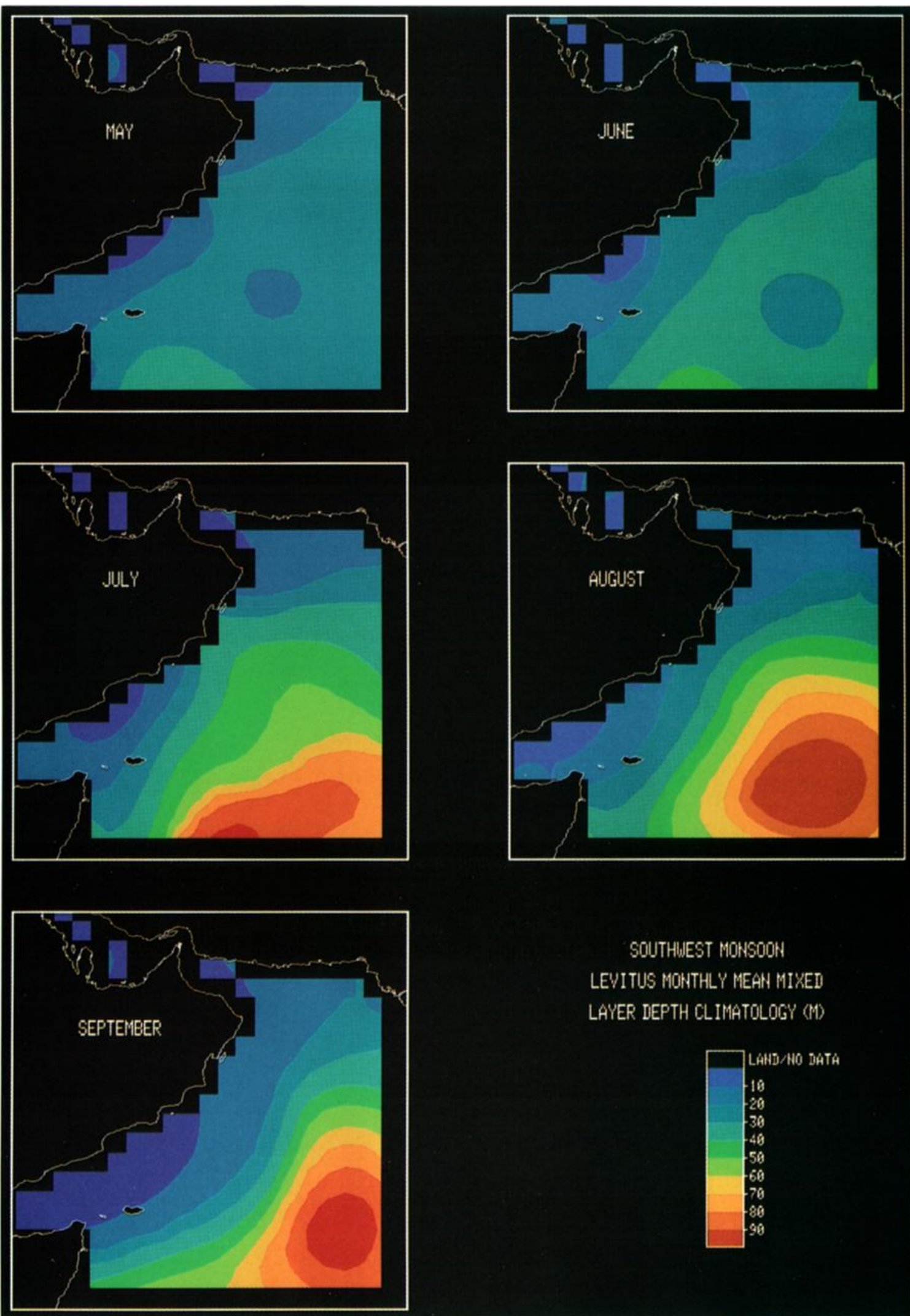

SOUTHWEST MONSOON

\section{LEVITUS MONTHLY MEAN MIXED} LAYER DEPTH CLIMATOLOCY (M)

Plate 6. Levitus monthly mixed-layer depth chmatology for May-September [Le'vtius, 1982].

lowest temperatures are off the coasts of Arabia and Somalia, where the mean temperatures drop to $22^{\circ}-23^{\circ} \mathrm{C}$.

Previous individual observations have revealed even colder temperatures during the southwest monsoon. The
R/V Argo survey of August-September 1964 measured temperatures lower than $14^{\circ} \mathrm{C}$ off Somalia [Stommel and Wooster. 1965]. The R. R. S. Discovery survey of JulyAugust 1963 found $19^{\circ}$ water at the surface immediately 

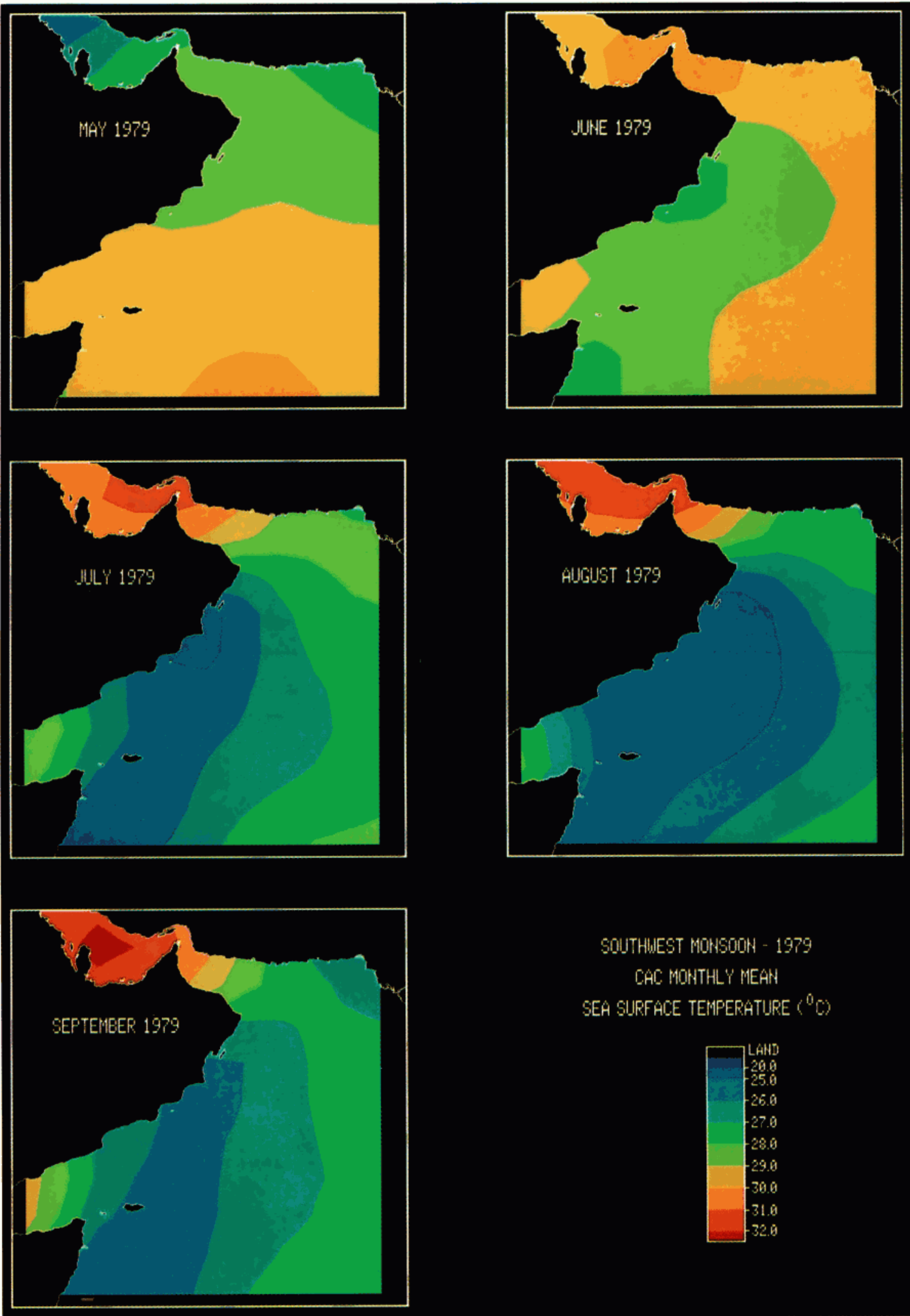

SOUTHUEST MONSOONA - 1979

CAC MONTHLY MEAH

SEA SIJRFACE TEMPERATURE $\left(0^{\circ} 0\right)$

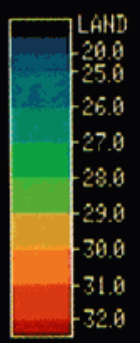

offshore of Oman [Currie et al., 1973]. The $2^{\circ}$ spatial resolution and monthly time averaging of the $\mathrm{CAC}$ data set is insufficient to resolve the surface temperature structure on this fine scale, and hence the coldest temperatures seen on the CAC field adjacent to Arabia in August 1979 are nowhere less than $20^{\circ} \mathrm{C}$.

\section{Vertical Temperature Fields}

The May surface temperatures shown on May XBT temperature section A (Figures 6 and $7 a$ ) are in general agreement with those of the monthly mean CAC SST field. The 
May 1979 XBT Section Locotion Mop

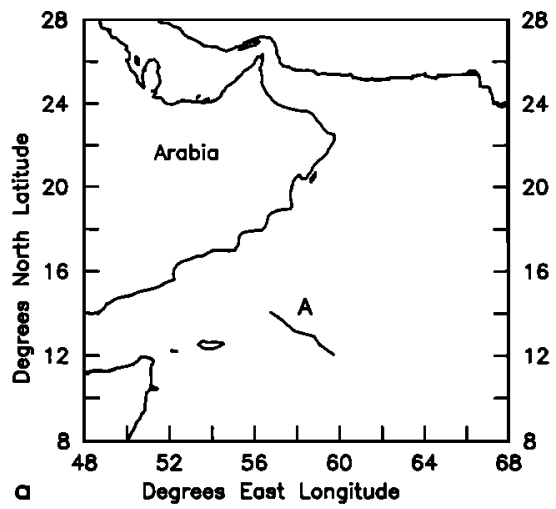

June 1979 XBT Section Location Map

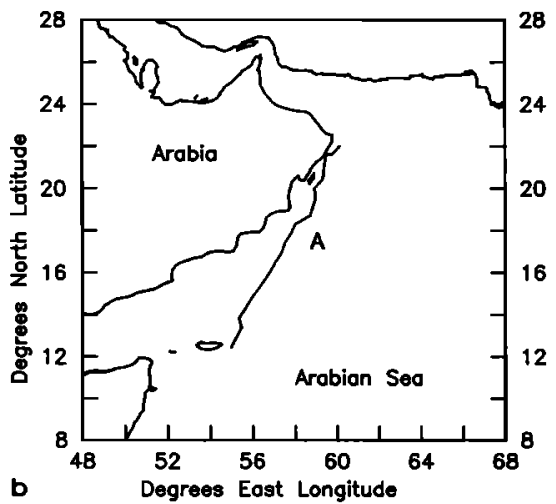

August 1979 XBT Section Locotion Mop

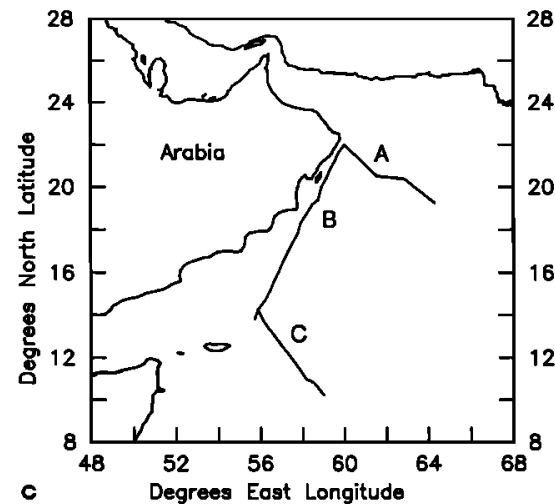

Fig. 6. Location maps for temperature sections based on expendable bathythermograph data.

$18^{\circ} \mathrm{C}$ isotherm, here taken to represent the base of the thermocline (J. C. Brock et al., manuscript in preparation, 1991), was at about $200 \mathrm{~m}$ depth and horizontal. June temperature section A (Figures 6 and $7 b$ ) extending $1200 \mathrm{~km}$ from Ras al Hadd at the northern end to the island of Socotra shows upward doming of the $18^{\circ} \mathrm{C}$ isotherm for over $700 \mathrm{~km}$, reaching a minimum depth about $350 \mathrm{~km}$ northeast of the island of Socotra. This location is near the center of the upward Ekman pumping region predicted by the FGGE winds analysis.

The three temperature sections for August (Figures 6, 7c, $7 d$, and $7 e$ ) reveal perturbations of the subsurface temperature structure that in general match the pattern of cooling seen on the August monthly mean CAC SST field. On August section A (Figures 6 and 7c), which extends from Ras al Hadd for over $500 \mathrm{~km}$ to the southeast, isotherms slope up toward the Arabian shore; at the landward end the $18^{\circ} \mathrm{C}$ isotherm is at a depth of about $90 \mathrm{~m}$. The position of August section $B$ (Figures 6 and $7 d$ ) nearly duplicates that of section $A$ for June. It shows that uplift of the $18^{\circ} \mathrm{C}$ isotherm to depths less than $100 \mathrm{~m}$ has propagated northeast along
Arabia to the entrance to the Gulf of Oman. This corresponds to the progression of the Ekman pumping field estimated from the FGGE winds. The position of August temperature section $\mathrm{C}$ (Figures 6 and $7 e$ ) approximates that of May section A. It shows strong uplift of cool water to the northwest, spatially coincident with the FGGE wind-derived region of upward Ekman pumping. On the August section the depth of the $18^{\circ} \mathrm{C}$ isotherm ranges from $150 \mathrm{~m}$ (southeast) to $60 \mathrm{~m}$ at its northwest extreme.

\section{Numerical Model Results}

All upward incremental displacements of the model interface are summed for the 2 months preceding June 16 (Plate $8 a$ ) and for the 2 months preceding August 16 (Plate $8 b$ ). These two periods correspond to the pre- and postmonsoon onset periods referred to above. Model upwelling during the early phases of the southwest monsoon begins off the coast of Somalia, to the south and west of Socotra, and in the west and north of the Gulf of Aden. This upwelling signal
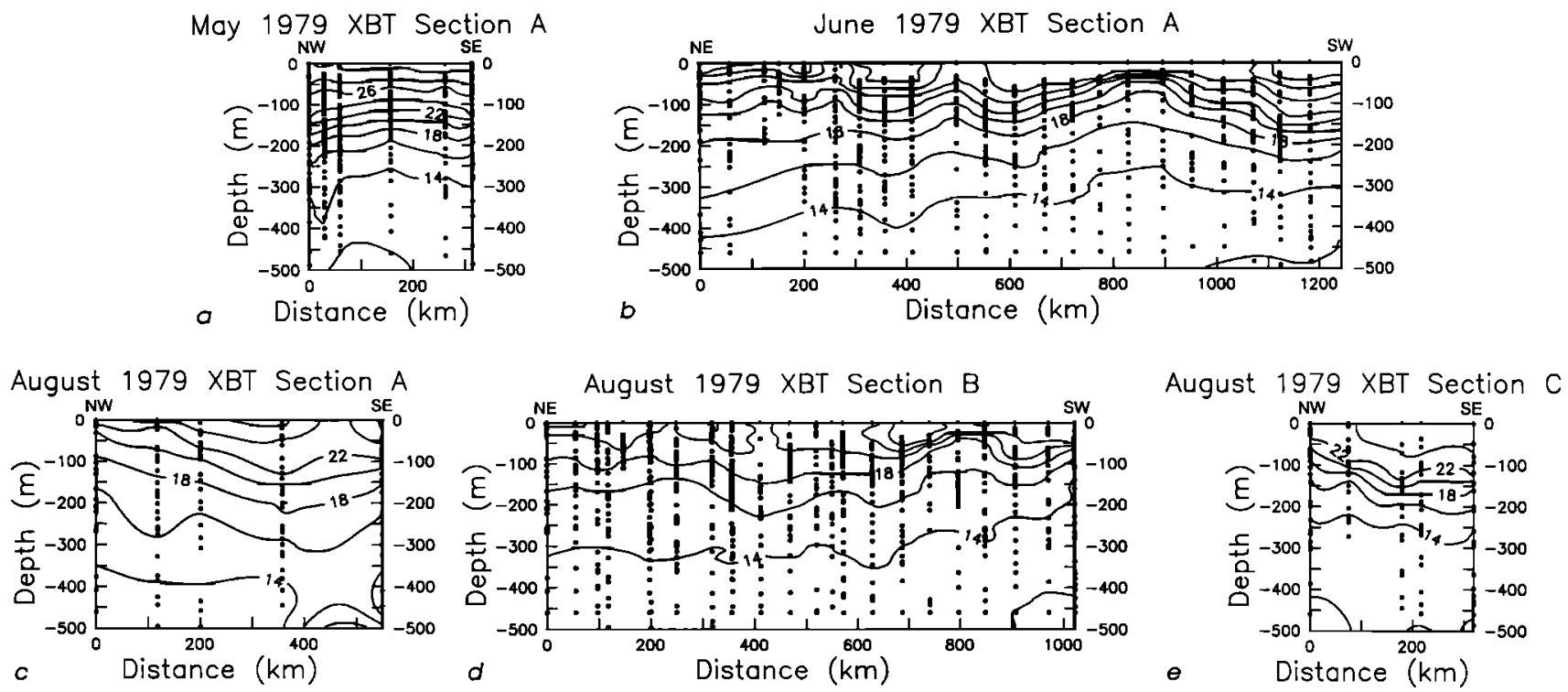

Fig. 7. (a) May 1979 XBT temperature section A. (b) June 1979 XBT temperature section A. (c) August 1979 XBT temperature section A. (d) August 1979 XBT temperature section B. (e) August 1979 XBT temperature section C. (See Figure 6 for locations). 

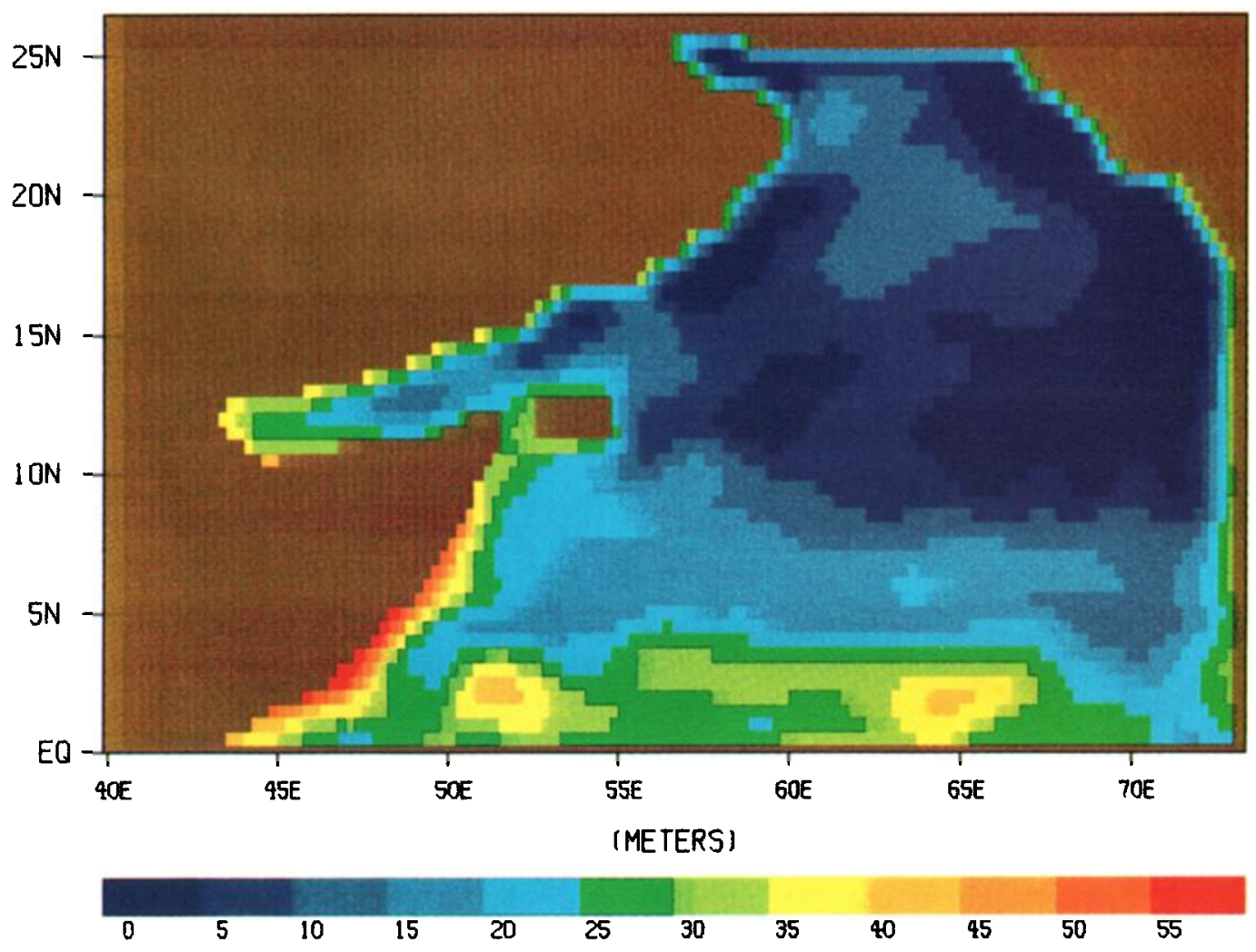

Plate $8 a$
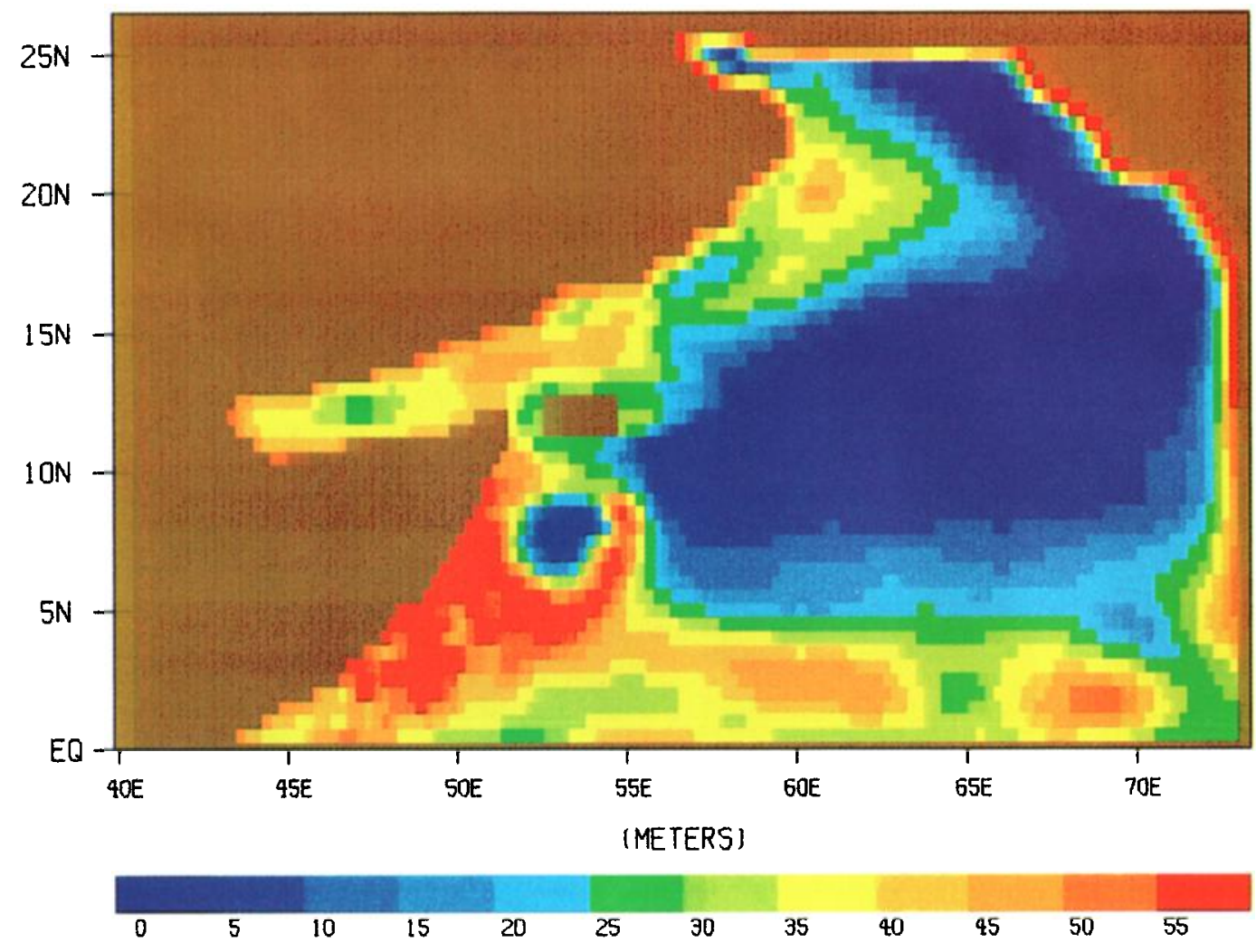

Plate 86

Plate 8. Model representation of summed upward interface displacement for the 2-month periods ending on (a) June 16, 1979, and (b) August 16, 1979. 
progresses northward as the monsoon intensifies. The most active upwelling occurs during the period of mid-June to mid-August. Upwelling prior to June 16 is confined to the coastal region and has the character of classical coastal upwelling. Upwelling after June 16 off Arabia extends much farther offshore and has a maximum at the coast and another maximum beneath the area of strong cyclonic wind stress curl associated with the Somali Jet. This model upwelling signal is consistent with the analysis of Smith and Bottero [1977]. The broad upwelling band that extends out to the core of the Somali Jet is driven directly by the wind stress curl through upward Ekman pumping. The patchiness of the upwelling signal is probably caused by the eddy field and planetary wave field that is superposed on and interacts with the Ekman pumping mechanism [Luther et al., 1985; Simmons et al., 1988].

The high values of upwelling off the coast of Somalia are due to the formation of the upwelling wedges in the two gyre system of the Somali Current and due to the northward movement of the Great Whirl. The center of the Great Whirl is indicated by the area of low upward interface displacement located at $8^{\circ} \mathrm{N}, 53^{\circ} \mathrm{E}$, since this is an area of deepening of the thermocline. Much of the narrow band of coastal upwelling that is seen along the coast of the northeastern Arabian Sea is driven by the rectification of coastal Kelvin waves. Similarly, high values of upward interface displacement along the equatorial wave guide have been attributed to the rectification of equatorially trapped waves [Luther et al., 1985; Simmons et al., 1988].

\section{Discussion}

\section{Vertical Mixing}

Extensive previous work has established that within many portions of the world ocean, vertical mixing is associated with abundant plant and animal biomass [McGowan and Hayward, 1978; Marra, 1980]. Recently, Banse and McClain [1986] observed that winter mixing of the northern Arabian Sea primarily due to surface cooling and mechanical stirring promotes enhanced algal production, raising the possibility that mechanical convection might act to enhance phytoplankton biomass during the summer monsoon. The July FGGE monthly mean wind stress field across the northwestern Arabian Sea (Plate 3) provides an indication of the relative distribution of the potential for mixing. The wind stress high beneath the Somali Jet $650 \mathrm{~km}$ east of the Somali coast is more than $700 \mathrm{~km}$ south of the core of the phytoplankton bloom seen on the CZCS late phase composite. Although the exact role of vertical mixing is uncertain, this suggests that it is not a dominant process in the stimulation of the regional bloom.

\section{Coastal Upwelling}

The Ekman model explains coastal upwelling as the consequence of the offshore transport of a wind-driven surface current due to the Coriolis effect. Within this model the balance between friction and Coriolis forces implies divergence away from the coastal boundary and upwelling [ $S$ mith, 1968]. Large gradients in the surface physical, chemical, and biological properties of the ocean are created by upwelling. The upward movement of subnutracline waters causes the intense phytoplankton blooms and dense zooplankton patches that are typical of these zones [Barber and Smith, 1981; Dugdale, 1983; Smith, 1983; Packard et al., 1984].

Coastal upwelling in the western Arabian Sea is unique in that it is monsoon driven, occurring only in summer during the active period of the southwest monsoon [Wyrtki, 1973]. Bottero [1969] conducted a detailed study of the summer field of motion off Arabia using hydrographic data obtained by the R. R. S. Discovery in June and July of 1963. His analysis indicated northeastward nearshore geostrophic flow velocities between 0.25 and $0.5 \mathrm{~m} / \mathrm{s}$, the presence of three large eddies, and intense upwelling within a narrow band along the Oman coast. The total offshore wind-induced transport in the study region was calculated to be $14 \times 10^{6}$ $\mathrm{m}^{3} / \mathrm{s}$, balanced by the surface current from the southwest, and to a lesser extent, shoreward flow at depth [Bottero, 1969].

Upwelling along the Arabian coast in the summer of 1979 is indicated by the XBT vertical temperature observations and the wind-driven numerical modelling of circulation. The coastward shoaling of the $18^{\circ} \mathrm{C}$ isotherm on August XBT temperature section $\mathrm{A}$ is inferred to result from coastal upwelling (Figures 6 and $7 c$ ). Upward displacement of an interface representing the Arabian Sea pycnocline produced by the numerical model also suggests coastal upwelling along Arabia. Upward interface movement summed over the time period of April 17 to June 16, 1979, reaches $25 \mathrm{~m}$ within a narrow strip along the Oman coast [Plate $8 a$ ]. The summation of upward model interface movement for the subsequent 2-month time period, June 17 to August 16, 1979, depicts a more intense coastal strip of upwelling that reaches $50 \mathrm{~m}$ inshore (Plate $8 b$ ).

The numerical model predictions of Oman coastal upwelling beginning during the early onset phase and persisting though the peak period of the southwest monsoon are consistent with the phytoplankton biomass distributions inferred from the CZCS composites. On both the early and late phase monsoon CZCS composites, the Oman continental shelf is a region of high surface pigment concentration. Depicted on the early phase composite is a sharp pigment gradient at about the position of the continental shelf edge that separates the eutrophic coastal water from low-pigment water further offshore (Plate 1). Within the extensive bloom seen on the late phase composite, a strong oceanward pigment gradient still exists at the continental shelf edge, although the background pigment concentration is greatly increased (Plate 2).

\section{Ekman Pumping}

Bottero's [1969] analysis of the Discovery data indicated that wind stress increased with distance offshore, yielding divergent Ekman flow and creating an upwelling area extending $1000 \mathrm{~km}$ along the Oman coastline and out $400 \mathrm{~km}$ into the Arabian Sea. Smith and Bottero [1977] estimated that during the height of the southwest monsoon, the total upward transport at 50 -m depth within this region is $8 \times 10^{6}$ $\mathrm{m}^{3} / \mathrm{s}$. Vertical velocities in the range of 1 to $2 \times 10^{-5} \mathrm{~m} / \mathrm{s}$ were calculated at $50 \mathrm{~m}$, dropping to about $0.4 \times 10^{-3} \mathrm{~m} / \mathrm{s}$ at $700 \mathrm{~m}$ depth. This Ekman pumping was indicated to cause strong upward motion to depths in excess of $700 \mathrm{~m}$ [Bottero, 1969].

The dominant influences on northwestern Arabian Sea surface and mixed-layer temperature in summer are the 
wind-driven upwelling of cooler water and surface heat fluxes [Düing and Leetmaa, 1980; Molinari et al., 1986; $M c C r e a r y$ and Kundu, 1989]. Since the net surface heat flux was positive north of the Somali Jet [Molinari et al., 1986] in 1979, cooling depicted on the CAC monthly mean SST fields may be interpreted as the coarse scale distribution of Ekman pumping in the northwestern Arabian Sea. This inference is supported by previous studies of the summertime mixedlayer heat budget of the Arabian Sea. Although coastal upwelling also must affect SST [Bruce, 1974], given the space scale of this process and its restriction to a narrow coastal fringe within the Rossby radius of deformation, the $2^{\circ}$ spatial resolution of the CAC monthly mean temperature fields is regarded as appropriate only to the inference of open-sea upwelling.

The onset of surface temperature cooling in the northwestern Arabian Sea during June 1979 (Plate 7) was correlated in space and time with the development of upward Ekman pumping in a $400 \mathrm{~km}$ wide zone trending southwestnortheast from the Horn of Africa to the Gulf of Oman. The most intense depression of SST seen on the CAC data set lagged the peak open-sea upwelling calculated from the FGGE winds by 1 month (Plate 5). The CAC SSTs reached a minimum in August 1979 and dropped about $6^{\circ} \mathrm{C}$ from May to August. On the mean field for this month, SST is below $27^{\circ} \mathrm{C}$ over most of the Arabian Sea. Possible explanations for the eastward extension of cool SSTs beyond the upwelling region include latent heat transfer from ocean to atmosphere at the axis area of the Somali Jet and advection of cool upwelled water into the central portion of the Arabian Sea.

The shoaling of isotherms at the northwest end of August temperature section $\mathrm{C}$ (Figure 7e) relative to May (Figure 7a) also suggests upward Ekman pumping. The $18^{\circ} \mathrm{C}$ isotherm rose from about $120 \mathrm{~m}$ in May to $95 \mathrm{~m}$ in August. The greatest rise was near the core of the upward Ekman pumping region calculated for July (Plate 5).

Surface pigment concentrations seen on the CZCS late phase composite (Plate 2) correlate with the July monthly mean CAC SST field (Plate 7). The phytoplankton bloom depicted was characterized by pigment concentrations above $1.5 \mathrm{mg} / \mathrm{m}^{3}$ and extended to about $65^{\circ} \mathrm{E}$ offshore of the very high pigment Oman continental shelf region. This open ocean portion of the phytoplankton bloom paralleled the Oman shelf and extended $700 \mathrm{~km}$ to the southeast into the Arabian Sea. This offshore bloom region corresponds to the zone of upwelling shown on the FGGE-based Ekman pumping fields for June, July, and August (Plate 5). Although the late phase CZCS composite is incomplete near Socotra Island in the much more dynamically active and complex region of the Somali Current, it appears that here high pigment did not correspond with sea surface cooling as shown on the CAC SST data, or with the Ekman upwelling predicted from the FGGE winds.

The numerical model upwelling index is well correlated with southwest monsoon phytoplankton biomass (Plate $8 b$ ). The model upwelling index for the period mid-June to mid-August shows an east-west boundary to the north of the island of Socotra separating a zone of strong upward motion exceeding $40 \mathrm{~m}$ off southern Oman and Yemen from a region exhibiting upward displacements around $25 \mathrm{~m}$ to the south. This model result coincides with the pigment concentration boundary seen on the late phase pigment composite at about $12^{\circ} \mathrm{N}$, marking the southward limit of the phytoplankton bloom.

The pattern of model upwelling for the post-monsoon onset period in general agrees with the monthly mean Ekman upwelling velocity fields calculated from the FGGE wind data. An area of open-sea upwelling adjacent to both the northern and southern Arabian Sea coast of Oman is suggested by a zone of upward interface displacement reaching $50 \mathrm{~m}$ over an area of $400 \mathrm{~km}$ breadth. This region of model upwelling differs in detail from the wind-derived Ekman upwelling fields most significantly in the presence of an upward displacement low off central Oman at about $17.5^{\circ} \mathrm{N}$, $57^{\circ} \mathrm{E}$. No pronounced drop in surface pigment concentration is seen at this site on the late phase CZCS composite. In the model, this feature arises from the formation of a warm or anticyclonic eddy at that location. Although this eddy is not seen in pigment concentration, there is evidence for alternating warm and cold eddies along the Arabian Peninsula in the XBT sections for June and August (Figures $7 b$ and $7 d$ ) as was seen by Simmons et al. [1988] for this region in 1985 .

Unlike the Ekman upwelling analysis based solely on the wind fields, the numerical circulation model is sensitive to the effect of Arabia as a basin boundary, which is approximated by the $200-\mathrm{m}$ isobath. Accordingly, the model simulates and provides evidence for coastal upwelling within a roughly $75-\mathrm{km}$-wide fringe along Arabia from Ras al Hadd to the Gulf of Aden. The model interface is displaced upward approximately 45 to $50 \mathrm{~m}$ in this band during the postmonsoon-onset period of mid-June to mid-August.

The numerical model does not admit the effects of mechanical mixing, convective overturning, or offshore advection of upwelled water; yet the model-derived upwelling patterns are consistent with the observed distribution of pigment concentration. This indicates that the mechanisms of coastal upwelling and open-ocean upwelling are the dominant mechanisms controlling the distribution of pigment concentration. Coastal upwelling is effective only within one internal Rossby radius from the shore (about $50 \mathrm{~km}$ ), whereas the space scale of the broad band of open-ocean upwelling is determined by the distribution of the wind stress curl. This region is unique among the world's oceans in that high values of positive wind stress curl persist for 3 months over a large area due to the jetlike nature of the atmospheric flow.

On a regional scale the Levitus monthly mixed-layer depth fields support the Ekman pumping distributions calculated from the winds and the numerical circulation model. The mixed-layer deepening in the central Arabian Sea shown on the Levitus charts for July through August (Plate 6) coincides with downwelling on the FGGE-based Ekman vertical velocity fields for June through August. The model interface deepens dramatically in this region under the influence of downward Ekman pumping driven by the negative wind stress curl to the south and east of the Somali Jet. Thus, convergence in the central Arabian Sea under the southwest monsoon atmospheric circulation appears to result in mixedlayer thickening, thermocline deepening and downwelling.

\section{Offshore Advection of Pigment-Rich Shelf Waters}

Banse [1987] suggested that during the summer season, nutrient-laden water upwelled at the Arabian coast is advected into Colburn's [1975] hydrographic areas 2 and 3. 
Banse [1987] reported low-salinity water over $800 \mathrm{~km}$ oceanward of Arabia, concluding that this was evidence for extensive advection. The hydrographic overview of the northwestern Arabian Sea of Premchand et al. [1986] calls into question the validity of this conclusion. They noted that immediately adjacent to Arabia the Arabian Sea Surface Water, the Persian Gulf Water, and the Red Sea Water coalesce to form a nearly isohaline layer in the upper $1000 \mathrm{~m}$; hence upwelling should not result in fresher surface water. Bruce [1974] did not find strong decreases in surface salinities, and the July-August surface salinity chart of Wyrtki [1971] shows only slightly lower salinities off the Arabian coast.

Eastward advection of surface water is predicted by the monthly mean total surface Ekman transport calculated from the FGGE winds. Horizontal Ekman transport approaches $1.0 \mathrm{~m}^{2} / \mathrm{s}$ in July at the Arabian shore and increases to more than $3.0 \mathrm{~m}^{2} / \mathrm{s} 600 \mathrm{~km}$ offshore to the southeast. Further, the zones of convergence and divergence suggested by the Ekman pumping and the thickening of the mixed layer in the central Arabian Sea both imply offshore advection. However, on the basis of the preceding discussions it is concluded that local vertical processes provide the nutrients regarded to support the summer bloom, rather than the horizontal advection of nutrients from the region of coastal upwelling. Phytoplankton blooms occur on time scales too short to be explained by nutrient advection on a basin scale. It should be noted that squirts similar to those that occur off promontories along the U.S. west coast are found off Arabia [Kelly, 1985; Kosro and Huyer, 1986; Abbott and Zion, 1987]. These events can rapidly advect high-pigment water considerable distances offshore and may effect surface phytoplankton pigment concentration within the offshore bloom.

\section{Conclusions}

This study involved the synthesis of satellite ocean color remote sensing with the analysis of in situ hydrographic and meteorological data sets, and the results of a numerical upper ocean circulation model. The multidisciplinary approach has lead to the following conclusions:

1. The 1979 southwest monsoon phytoplankton bloom in the northwestern Arabian Sea peaked during AugustSeptember, extended from the Oman coast to about $65^{\circ} \mathrm{E}$, and lagged the development of open-sea upwelling by at least 1 month.

2. Vertical mixing does not appear to have been the dominant forcing mechanism of the regional-scale bloom in 1979.

3. The bloom was driven by spatially distinct local physical processes which forced upward nutrient fluxes to the euphotic zone, i.e., coastal upwelling in the nearshore zone and Ekman pumping in the offshore region. Coastal upwelling was evident from May through September; although it produced the highest concentrations of phytoplankton, its impact was limited to over and near the continental shelf. Ekman pumping resulted in development of a broad phytoplankton bloom oceanward of the Oman shelf.

4. Earlier suggestions that the widespread phytoplankton bloom in the open ocean region of the northwestern Arabian Sea could be attributed to advection of water upwelled along the Arabian coast are not supported by our analysis.
Acknowledgments. This research was conducted within the Oceans and Ice Branch at NASA Goddard Space Flight Center. J. Brock gratefully ackowledges support from the NASA Graduate Student Researchers Program. Funding for C. McClain was provided by NASA RTOPS 161-30-02, 161-30-21, and 161-80-51. The authors thank J. Firestone, E. Yeh, and M. Darzi of General Sciences Corporation for invaluable assistance in processing the satellite, wind, and hydrographic data sets. L. Olson and J. Vanderpool at the NASA Climate Data System aided in the acquisition of the FGGE and NOAA CAC data sets. The FSU wind fields were provided by David M. Legler and James J. O'Brien. The Indian Ocean modeling effort was supported through the Mesoscale AirSea Interaction Group at the Florida State University by the Office of Naval Research and by the National Atmospheric and Oceanic Administration. Partial support was provided by the Florida State University through time granted on their Cyber 205, ETA-10, and Cray Y/MP supercomputers.

\section{REFERENCES}

Abbott, M. R., and P. M. Zion, Satellite observations of upwelling variability during an upwelling event, Cont. Shelf Res., 4(6), 661-680, 1985.

Abbott, M. R., and P. M. Zion, Spatial and temporal variability of phytoplankton pigment off northern California during Coastal Ocean Dynamics Experiment 1, J. Geophys. Res., 92(C2), 1745$1755,1987$.

Aruga, Y., Primary production in the Indian Ocean, II, in The Biology of the Indian Ocean, edited by B. Zeitzschel, pp. 127130, Springer-Verlag, New York, 1973.

Banse, K., Seasonality of phytoplankton chlorophyll in the central and southern Arabian Sea, Deep Sea Res., 34, 713-723, 1987.

Banse, K., and C. R. McClain, Satellite-observed winter blooms of phytoplankton in the Arabian Sea, Mar. Ecol. Prog. Ser., 34, 201-211, 1986.

Barale, V., C. R. McClain, and P. Malanotte-Rizzoli, Space and time variability of the surface color field in the northern Adriatic Sea, J. Geophys. Res., 91(C11), 12,957-12,974, 1986.

Barber, R. T., and R. L. Smith, Coastal upwelling ecosystems, in Analysis of Marine Ecosystems, edited by A. R. Longhurst, pp. 31-69, Academic, San Diego, Calif., 1981.

Bauer, S., G. L. Hitchcock, and D. B. Olson, Influence of monsoonally-forced Ekman dynamics upon surface layer depth and plankton biomass distribution in the Arabian Sea, Deep Sea Res., 38, 531-553, 1991.

Bottero, J. S., An Analysis of Upwelling off the Southeast Arabian Coast during the summer monsoon, 70 pp., M. S. thesis, Oreg. State Univ., Corvallis, 1969.

Brewer, P. G., K. W. Bruland, R. W. Eppley, and J. J. McCarthy, The global ocean flux study (GOFS): Status of the U.S. GOFS program, Eos Trans. AGU, 67(44), 827-832, 1986.

Brock, J. C., C. R. McClain, and W. W. Hay, Southwest monsoon upwelling and surface phytoplankton pigment along the Oman Arabian Sea coast (abstract), Eos Trans. AGU, 71, 532-533, 1990.

Bruce, J. G., Some details of upwelling off the Somali and Arabian coasts, J. Mar. Res., 32, 419-423, 1974.

Camerlengo, A. L., and J. J. O'Brien, Open boundary conditions in rotating fluids, J. Comput. Phys., 35, 12-35, 1980.

Colburn, J. G., The Thermal Structure of the Indian Ocean, 173 pp., University of Hawaii Press, Honolulu, 1975.

Currie, R. I., A. E. Fisher, and P. M. Hargreaves, Arabian Sea upwelling, in The Biology of the Indian Ocean, edited by B. Zeitzschel, pp. 37-52, Springer-Verlag, New York, 1973.

Darzi, M., J Chen, J. Firestone, and C. McClain, SEAPAK: A satellite image analysis system for oceanographic research, in Proceedings of Fifth Conference on Interactive and Information Processing Systems for Meteorology, Hydrography, and Oceanography, pp. 26-32, American Meteorological Society, Boston, Mass., 1989.

Dugdale, R. C., Effects of source nutrient concentrations and nutrient regeneration on production of organic matter in coastal upwelling centers, in Coastal Upwelling-Its Sediment Record, Part A, Responses of the Sedimentary Regime to Present Coastal Upwelling, edited by E. Suess and J. Thiede, pp 175-182, Plenum, New York, 1983.

Düing, W., and A. Leetmaa, Arabian Sea cooling: A preliminary heat budget, J. Phys. Oceanogr., 10, 307-312, 1980. 
Esaias, W. E., Remote sensing of oceanic phytoplankton: Present capabilities and future goals, in Primary Productivity in the Sea, edited by P. G. Falkowski, pp. 321-337, Plenum, New York, 1980.

Feldman, G., D. Clark, and D. Halpern, Satellite color observations of the phytoplankton distribution in the eastern equatorial Pacific during the 1982-1983 El Niño, Science, 226, 1069-1071, 1984.

Feldman, G., et al., Ocean color: Availability of the global data set, Eos Trans. AGU, 70(23), 634-635, 640-641, 1989.

Findlater, J., A major low-level air current near the Indian Ocean during the northern summer, $Q$. J. R. Meteorol. Soc., 95, 362$380,1969 a$.

Findlater, J., Interhemispheric transport of air in the lower troposphere over the western Indian Ocean, Q. J. R. Meteorol. Soc., $95,400-403,1969 b$.

Findlater, J., The low-level cross-equatorial air current of the western Indian Ocean during the northern summer, Weather, 29 , $411-416,1974$.

Findlater, J., Observational aspects of the low-level cross-equatorial jet stream of the western Indian Ocean, Pure Appl. Geophys., $115,1251-1261,1977$.

Findlater, J., An experiment in monitoring cross-equatorial airflow at low level over Kenya and rainfall of western India during the northern summers, in Monsoon Dynamics, edited by J. Lighthill and R. P. Pearce, chap. 20, Cambridge University Press, New York, 1981.

$\mathrm{Fu}, \mathrm{C}$., J. Fletcher, and R. Slutz, The structure of the Asian monsoon surface wind field over the ocean, J. Clim. Appl. Meteorol., 22, 1242-1252, 1983.

Gent, P. R., K. O'Neill, and M. A. Crane, A model of the semiannual oscillation in the equatorial Indian Ocean, J. Phys. Oceanogr., 13, 2148-2160, 1983.

Gordon, H. R., Radiometric considerations for ocean color remote sensors, Appl. Opt., 29(22), 3228-3236, 1990.

Gordon, H. R., and D. K. Clark, Clear water radiances for atmospheric correction of coastal zone color scanner imagery, Appl. Opt., 20, 4175-4180, 1981 .

Gordon, H. R., D. K. Clark, J. W. Brown, O. B. Brown, R. H. Evans, and W. W. Broenkow, Phytoplankton pigment concentrations in the Middle Atlantic Bight: Comparison of ship determinations and CZCS estimates, Appl. Opt., 22(1), 20-36, 1983.

Hastenrath, S., and P. Lamb, Climatic Atlas of the Indian Ocean, Part I, Surface Circulation and Climate, 109 pp., University of Wisconsin Press, Madison, 1979.

Kabanova, Y. G., Primary production of the northern part of the Indian Ocean, Oceanology, 8(2), 214, 1968.

Kelly, K. A., The influence of winds and topography on the sea surface temperature patterns over the northern California slope, J. Geophys. Res., 90(C6), 11,783-11,798, 1985.

Kosro, P. M., and A. Huyer, CTD and velocity surveys of seaward jets off northern California, July 1981 and 1982, J. Geophys. Res., 91(C6), 7680-7690, 1986.

Krey, J., Primary productivity in the Indian Ocean, I, in The Biology of the Indian Ocean, edited by B. Zeitzschel, pp. 115-126, Springer-Verlag, New York, 1973.

Krishnamurti, T. N., P. Ardanuy, Y. Ramanathan, and R. Pasch, On the onset vortex of the summer monsoon, Mon. Weather Rev., $109,344-363,1981$.

Kuz'menko, L. V., Distribution of phytoplankton in the Arabian Sea, Mar. Biol., 17(1), 70-74, 1973.

Large, W. G., and S. Pond, Open ocean momentum measurements in moderate to strong winds, J. Phys. Oceanogr., 11, 324-336, 1981.

Legler, D. M., I. M. Navon, and J. J. O'Brien, Objective analysis of pseudostress over the Indian Ocean using a direct-minimization approach, Mon. Weather Rev., 117, 709-720, 1989.

Levitus, S., Climatological atlas of the world ocean, NOAA Prof. Pap. 13, 173 pp., U.S. Govt. Print. Off., Washington, D. C., 1982.

Lin, L. B., and H. E. Hurlburt, Maximum simplification of nonlinear Somali Current dynamics, in Monsoon Dynamics, edited by M. J. Lighthill and R. P. Pearce, pp. 541-555, Cambridge University Press, New York, 1981.

Luther, M. E., Indian Ocean modelling, in Further Progress in Equatorial Oceanography, edited by E. Katz and J. Witte, pp. 303-316, Nova University Press, Dania, Fla., 1987.

Luther, M. E., and J. J. O'Brien, A model of the seasonal circula- tion in the Arabian Sea forced by observed winds, Prog. Oceanogr., 14, 353-385, 1985.

Luther, M. E., J. J. O'Brien, and A. Meng, Morphology of the Somali Current system during the southwest monsoon, in Coupled Ocean-Atmosphere Models, edited by J. C. J. Nihoul, pp. 405-437, Elsevier, New York, 1985.

Luther, M. E., J. J. O'Brien, and W. L. Prell, Variability in upwelling fields in the northwestern Indian Ocean, 1, Model experiments for the last 18,000 years, Paleoceanography, 5, 433-445, 1990.

Marra, J., Vertical mixing and primary productivity, in Primary Productivity in the Sea, edited by P. G. Falkowski, pp. 121-137, Plenum, New York, 1980.

McClain, C. R., L. J. Pietrafesa, and J. A. Yoder, Observations of Gulf Stream-induced and wind-driven upwelling in the Georgia Bight using ocean color and infrared imagery, J. Geophys. Res., 89(C3), 3705-3723, 1984.

McClain, C. R., S. Chao, L. P. Atkinson, J. O. Blanton, and F. De Castillejo, Wind-driven upwelling in the vicinity of Cape Finisterre, Spain, J. Geophys. Res., 91(C7), 8470-8486, 1986.

McClain, C. R., J. A. Yoder, L. P. Atkinson, J. O. Blanton, T. N. Lee, J. J. Singer, and F. Müller-Karger, Variability of surface pigment in the south Atlantic bight, J. Geophys. Res., 93(C9), 10,675-10,697, 1988.

McClain, C. R., W. E. Esaias, G. C. Feldman, J. Elrod, D. Endres, J. Firestone, M. Darzi, R. Evans, and J. Brown, Physical and biological processes in the north Atlantic during the First GARP Global Experiment, J. Geophys. Res., 95(C10), 18,027-18,048, 1990.

McCreary, J. P., and P. K. Kundu, A numerical investigation of sea surface temperature variability in the Arabian Sea, J. Geophys. Res., 94(C11), 16,097-16,114, 1989.

McGill, D. A., Light and nutrients in the Indian Ocean, in The Biology of the Indian Ocean, edited by B. Zeitzschel, pp. 53-102, Springer-Verlag, New York, 1973.

McGowan, J. A., and T. L. Hayward, Mixing and oceanic productivity, Deep Sea Res., 25, 771-793, 1978.

Molinari, R. L., J. Swallow, and J. F. Festa, Evolution of the near-surface thermal structure in the western Indian Ocean during FGGE, 1979, J. Mar. Res., 44, 739-763, 1986.

Moore, B., and B. Bolin, The oceans, carbon dioxide, and global climate change, Oceanus, 29(4), 9-15, 1986.

Mueller, J. L., Nimbus-7 CZCS: Electronic overshoot due to cloud reflectance, Appl. Opt., 27(3), 438-440, 1988.

Müller-Karger, F. E., C. R. McClain, T. R. Fisher, W. E. Esaias, and R. Varela, Pigment distribution in the Caribbean Sea: Observations from space, Prog. Oceanogr., 23, 23-64, 1989.

Müller-Karger, F. E., C. R. McClain, R. N. Sambrotto, and G. C. Ray, A comparison of ship and coastal zone color scanner mapped distribution of phytoplankton in the southeastern Bering Sea, J. Geophys. Res., 95(C7), 11,483-11,499, 1990.

Packard, T. T., D. Blasco, and R. C. Dugdale, Coastal upwelling: A synopsis of its physical, chemical and biological characteristics, in Marine Geology and Cceanography of Arabian Sea and Coastal Pakistan, edited by B. U. Haq and J. D. Milliman, pp. 339-350, Van Nostrand Reinhold, New York, 1984.

Pearce, R. P., and U. C. Mohanty, Onsets of the Asian summer monsoon 1979-82, J. Atmos. Sci., 41, 1620-1639, 1984.

Pickard, G. L., and W. J. Emery, Descriptive Physical Oceanography, 249 pp., Pergamon, New York, 1982.

Platt, T., and S. Sathyendranath, Oceanic primary production: Estimation by remote sensing at local and regional scales, Science, 241, 1613-1620, 1988.

Prell, W. L., R. E. Marvil, and M. E. Luther, Variability in upwelling fields in the northwestern Indian Ocean, 2, Data-model comparison at 9000 years B.P., Paleoceanography, 5, 447-457, 1990.

Premchand, K., J. S. Sastry, and C. S. Murty, Watermass structure in the western Indian Ocean, II, The spreading and transformation of the Persian Gulf Water, Mausam, 37(2), 179-186, 1986.

Qasim, S. Z., Biological productivity of the Indian Ocean, Indian J. Mar. Sci., 6, 122-137, 1977.

Qasim, S. Z., Oceanography of the northern Arabian Sea, Deep Sea Res., Part A, 9(9), 1041-1068, 1982.

Ryther, J. H., and D. W. Menzel, On the production, composition, 
and distribution of organic matter in the western Arabian Sea, Deep Sea Res., 12, 199-209, 1965.

Ryther, J. H., J. R Hall, A. K. Pease, A. Bakun, and M. M. Jones, Primary organic production in relation to the chemistry and hydrography of the western Indian Ocean, Limnol. Oceanogr., $11,371-380,1966$.

Simmons, R. C., M. E. Luther, J. J. O'Brien, and D. M. Legler, Verification of a numerical model of the Arabian Sea, J. Geophys. Res., 93, 15,437-15,461, 1988.

Smith, R. L., Upwelling, Oceanogr. Mar. Biol., 6, 11-46, 1968.

Smith, R. L., Circulation patterns in upwelling regimes, in Coastal Upwelling-Its Sediment Record, Part A, Responses of the Sedimentary Regime to Present Coastal Upwelling, edited by E. Suess and J. Thiede, pp. 13-35, Plenum, New York, 1983.

Smith, R. L., and J. S. Bottero, On upwelling in the Arabian Sea, in A Voyage of Discovery, edited by M. Angel, pp. 291-304, Pergamon, New York, 1977.

Stommel, H., and W. S. Wooster, Reconnaissance of the Somali Current during the southwest monsoon, Proc. Natl. Acad. Sci. U.S.A., 54, 8-13, 1965.

Swallow, J. C., Some aspects of the physical oceanography of the Indian Ocean, Deep Sea Res., 31, 639-650, 1983.

Thompson, K. R., R. F. Marsden, and D. G. Wright, Estimation of low-frequency wind stress fluctuations over the open ocean, $J$. Phys. Oceanogr., 13, 1003-1011, 1983.

Wooster, W. S., M. B. Schaefer, and M. K. Robinson, Atlas of the
Arabian Sea for fishery oceanography, Ref: IMR 67-12, 35 pp., Inst. of Mar. Resour., Univ. of Calif., La Jolla, 1967.

Wyrtki, K., Oceanographic Atlas of the International Indian Ocean Expedition, 531 pp., National Science Foundation, Washington, D. C., 1971 .

Wyrtki, K., Physical oceanography of the Indian Ocean, in The Biology of the Indian Ocean, edited by B. Zeitzschel, pp. 18-36, Springer-Verlag, New York, 1973.

Yentsch, C. S., Remote sensing of biological substances, in Remote Sensing Applications in Marine Science and Technology, edited by A. P. Cracknell, pp. 263-297, D. Reidel, Norwell, Mass., 1983.

J. C. Brock, Biological Oceanography Division, Bedford Institute of Oceanography, P. O. Box 1006, Dartmouth, Nova Scotia, Canada B2Y 4A2.

W. W. Hay, Cooperative Institute for Research in Environmental Sciences, University of Colorado, Boulder, CO 80309.

M. E. Luther, Department of Marine Science, University of South Florida, Saint Petersburg, FL 33701.

C. R. McClain, Oceans and Ice Branch, NASA Goddard Space Flight Center, Greenbelt, MD 20771.

(Received December 4, 1990; accepted February 1, 1991.) 